九州大学学術情報リポジトリ

Kyushu University Institutional Repository

\title{
Crabs from the East China Sea, I. : Corystoidea and Brachygnatha Brachyrhyncha
}

Takeda, Masatsune

Zoological Laboratory, Department of Agriculture, Kyushu University

Miyake, Sadayoshi

Zoological Laboratory, Department of Agriculture, Kyushu University

https://doi.org/10.5109/22780

出版情報: 九州大学大学院農学研究院紀要. 14 (4)，pp.541-582，1968-11. Kyushu University バージョン：

権利関係 : 
Journal of Faculty of Agriculture, Kyushu University, Vol. 14, No. 4

November 30, 1968

\author{
Crabs from the East China Sea, I. \\ Corystoidea and Brachygnatha Brachyrhyncha* \\ Masatsune Ta кеда and Sadayoshi M гунке
}

A knowledge of the crabs from the East China Sea has remained much more incomplete than that of the Brachyura of the other areas. Only some species were fragmentarily described by some authors in their works on the Brachyura. At present, fortunately, the considerable numbers of the crabs, which were collected by Mr. Hideo Yamashita of the Seikai Regional Fisheries Research Laboratory, are at our disposal for study.

The present report is concerned with twenty-eight species of seven families, most of which are new to the East China Sea. The classification of the species dealt herewith is as follows.

Section Corystoidea

Family Cancridae

Cancer gibbosulus (de Haan, 1835)

Family Corystidae

Jonas distincta (de Haan, 1835)

Podocatactes hamifer Ortmann, 1893

Section Brachygnatha

Superfamily Brachyrhyncha

Family Portunidae

Parathranites orientalis (Miers, 1886)

Macropipus corrugatus (Pennant, 1777)

Charybdis (Gonioneptunus) bimaculata (Miers, 1886)

Thalamita sp.

Portunus gladiator Fabricius, 1798

Family Xanthidae

Paratergatis longimanus Sakai, 1965

Nanocassiope granulipes (Sakai, 1939)

Xantho cultripes Alcock, 1898

Actaea savignyi (H. Milne Edwards, 1834)

Calvactaea tumida Ward, 1933

* Contributions from the Zoological Laboratory, Faculty of Agriculture, Kyushu University, No. 386. 
Liomera boninensis (Odhner, 1925)

Actumnus forficigerus (Stimpson, 1858)

Glabropilumnus sodalis (Alcock, 1898), new comb.

Ralumia balssi Sakai, 1935

Family Goneplacidae

Carcinoplax longimanus (de Haan, 1835)

Carcinoplax vestita (de Haan, 1835)

Pilumnoplax sp.

Goneplax renoculis Rathbun, 1914

G oneplax nipponensis Y okoya, 1933

Typhlocarcinops transversa Tesch, 1918

Typhlocarcinops ocularia Rathbun 1914

Family Pinnotheridae

Pinnixa rathbuni Sakai, 1934

Asthenognathus inaequipes Stimpson, 1858

Xenophthalmus pinnotheroides White, 1846

Family Palicidae

Palicus hatusimaensis Sakai, 1963

In order to assign the crabs from the East China Sea their proper places in the Indo-Pacific fauna, it is necessary to compare them with the fauna of the other localities as a whole, especially with the West Pacific fauna. For purposes of discussion of the distribution the localities in literature are listed as fully as possible. As the complete discussion will be given in the end of the series of this study, here only the brief survey is mentioned. Most of the species except for the family Portunidae and some of the other families are restricted to the West Pacific.

1) Family Cancridae

It is peculiar that some species from the West Pacific are common or analogous with those from the Pacific coast of America. Cancer gibbosulus, which is closely related to the American Cancer branneri Rathbun, is commonly found from the entire coast of Japan northward to Aomori Pref ecture. It ranges also to North China, so that the record of the occurrence in the East China Sea is not so noticeable.

2) Family Corystidae

Podocatactes hamifer and Jonas distincta are very characteristic and have hitherto been known only from the Japanese waters. The former species is monotypic, while one of the congeners of the latter species, $J$. distincta formosae Balss, is known from Taiwan.

3) Family Portunidae

Though four of five species here listed are very widely distributed as usual case of the other members of the family, it is remarkable that one 
of them, Macropipus corrugatus, ranges through the Red Sea to the Mediterranean and European waters southward to the west coast of Africa. It is apparent that the present list of the species is by no means exhaustive.

4) Family Xanthidae

One of the species listed, Glabropilumnus sodalis (Alcock), which was originally referred to the genus Liomera and afterward to the genus Pilumnus by Odhner (1925), is still now somewhat questionable in its systematic status. Its type and additional localities are the Andaman and Maldive Islands, the Indian Ocean, and the Bonin Islands, the West Pacific. Micropanope granulipes, which was recently transferred to the genus Nanocassiope by Guinot (1967), has hitherto been known from Japan and South Africa. The first male pleopods of the materials from those far apart localities are so close each other that both materials are possible to be identical. Otherwise Calvactaea tumida, which is known as a commensal with alcyonarians, shows a peculiar mode of distribution that it is known from south-west and southeast Australia, and Japan. The other species with the exception of Actaea savgnyi are restricted to the West Pacific, of which Ralumiabalssi has hitherto been known only from the Sagami Bay.

5) Family Goneplacidae

Carcinoplax longimanus and Carcinoplax vestita are rather well known species. The former species is so widely distributed in the Indo-Pacific waters that the institution of the subspecific status gives rise to a problem. In view of growth-changes, however, the subspecific name seems to be scarcely necessary. In addition to those two species it may be possible that the more species are obtained in the East China Sea by the further collections, as in 1914 Rathbun recorded seven new species of the genus from the Philippines. Goneplax renoculis, Goneplax nipponensis and Typhlocarcinops ocularia are known from the restricted areas around southern Japan and Philippines. On the other hand Typhlocarcinops transversa has been known from Sumbawa and Sunda Strait, therefore it extends its known range farther northward to the East China Sea.

6) Family Pinnotheridae

In the collection the members of the genus Pinnotheres are not included. Most of the species of the genus Pinnixa are known to be the inhabitants of the Pacific coast of America, and only five species including P. rathbuni are known from the West Pacific. Otherwise Asthenognathus inaequipes is endemic in Japan, while Xenophthalmus pinnotheroides ranges from Japan throngh the West Pacific to the Gulf of Manaar, India, and the record of the occurrence in the Persian Gulf needs to be secured.

7) Family Palicidae

Palicus hatusimaensis, which was recently described from the Sagami Bay, is one of five species of the genus from Japan and its adjacent waters. The other 
four representatives of the genus are P. kyushuensis Yokoya, P.longimanus (Miyake), $\boldsymbol{P}$. amadaibai Sakai and $\boldsymbol{P}$. microfrons Sakai. They are known from the restricted areas respectively. Palicus hatusimaensis is rather commonly found in the East China Sea. The membes of the genus Crossotonotus are not comprised in the collection, which are also known from the limited areas. C. compressipes A. Milne Edwards is known from the South Pacific, C. spinipes (de Man) from the Central and West Pacific, C. gardinielli (Rathbun) from the Indian Ocean, and C. brevimanus (Ward) from Queensland, Australia.

\author{
Description of species \\ Family Cancridae \\ Cancer gibbosulus (de Haan,1835)
}

Corystes (Trichocera) gibbosulus de Haan, 1835, p. 45, pl. 2, fig. 4, pl. 13, fig. 3Japan.

Trichocera gibbosula: Stimpson, 1907, p. 87-Off north-east of Japan, $55 \mathrm{~m}$ deep. Trichocarcinus affinis Miers, 1879, p. 35-33” $19^{\prime} \mathrm{N}, 129^{\circ} 7.5^{\prime} \mathrm{E}, 90 \mathrm{~m}$ deep.

Cancer gibbosulus : Balss, 1922, p. 94-Sagami Bay and Nagasaki, Japan.

Cancer gibbosulus : Yokoya, 1933, p. 167-Japan (many localities along Pacific coast from near Shiriya-zaki, Aomori Pref. southward to southern Bungo Strait; around Goto Is., off Yamaguchi Pref. and east of Saishu-to I., Sea of Japan), 44-307 $\mathrm{m}$ deep.

Cancer gibbosulus : Sakai, 1934a, p. 306-Nagasaki, Japan.

Cancer gibbosulus : Sakai, 1936, p. 142, pl. 41, fig. 2-Japan.

Cancer gibbosulus : Sakai, 1939, p. 436, fig. 22, pl. 52, fig. 4, pl. 48, fig. 2- Off Talien, China; Iwate Pref., Sagami Bay, Suruga Bay and Kii, Japan.

Cancer gibbosulus : Miyake, 1961, p. 173-Sea of Ariaké, Japan.

Cancer gibbosulus : Sakai, 1965b, p. 105, pl. 47, fig. 3, pl. 48, fig. 2-Sagami Bay, $35-55 \mathrm{~m}$ deep.

\title{
Material examined :
}

1 우,ZLKU No. 12507; 27” 55’ N, 1233’ E, depth unknown; Apr. 9, 1962; H. Yamashita leg.

1 우 (15.9 x20.7 mm), ZLKU No. $8410 ; 30^{\circ} 29^{\prime} \mathrm{N}, 125^{\circ} 29^{\prime} \mathrm{E}, 65 \mathrm{~m}$ deep ; Jun. 14, 1957; H. Yamashita leg.

1 우, ZLKU No. 12582 ; 28” 45’. N, 125” 31' E, 99 m deep ; Jun. 13, 1963 ;H. Yamashita leg.

\section{Remarks :}

The anterolateral border is armed with nine teeth including the one at the external orbital angle ; there is otherwise a smaller tooth on the poste- 
rolateral border behind the last anterolateral tooth; those teeth are acute and triangular, being alternately larger and smaller. According to Sakai (1965b), however, in the larger individuals the anterolateral teeth are similar in size, having a tendency to be confluent with each other.

\section{Distribution :}

This species is mainly known from the Japanese waters ; it occurs northward to Shiriya-zaki, Aomori Prefecture along the Pacific coast, and to off the coast of Yamaguchi Prefecture and east of Saishu-to Island along the coast of the Sea of Japan. Otherwise it has been recorded from Talien, China. Its bathymetric range is from 33 to $307 \mathrm{~m}$.

\section{Family Corystidae}

\section{Jonas distincta (de Haan, 1835)}

Cancer (Corystes) distincta de Haan, 1835, p. 45, pl. 13, fig. Z-Japan.

Gomeza distincta: Balss, 1922, p. 114 (in discussion).

Gomeza distincta: Yokoya, 1933, p. 184-North of Nagato, Yamaguchi Pref,. $90 \mathrm{~m}$ deep.

Jonas distincta : Ward, 1933, p. 380 (in discussion- Japan).

Gomoza distincta: Sakai, 1934a, p. 301-Nagasaki, Japan.

Gemeza distincta : Sakai, 1936, p. 115, pl. 31, fig. 3-Japan.

Jonas distincta: Sakai, 1939, p. 369, pl. 42, fig. 2-Sagami Bay and Ise Bay.

Jonas distincta : Miyake, 1961, p. 172-Sea of Ariaké, Japan.

Jonas distincta : Sakai, 1965b, p. 109, pl. 50, fig. 1-Sagami Bay, 80-120 m deep.

Material examined :

1 đ $(41.9 \times 27.3 \mathrm{~mm})$, ZLKU No. 12583 ; definite locality and depth not available ; Apr. 7, 1962: H. Yamashita leg.

\section{Distribution :}

This species is restricted to the Japanese waters; it is known from the Sagami Bay southward to the Tosa Bay, the Pacific coast, and from Nagasaki and off Yamaguchi Prefecture, the Sea of Japan.

\section{Podocatactes hamifer Ortmann, 1893}

Podocatactes hamifer Ortmann, 1893, p. 29, pl. 3, fig. 1-Sagami Bay, Japan. Podocatactes hamifer : Balss, 1922, p. 115-Sagami Bay, $80 \mathrm{~m}$ deep, and Uraga Strait, $90 \mathrm{~m}$ deep. 
Podocatactes hamifer : Yokoya, 1933, p. 179-Japan (many localities from Tsugaru Strait, Aomori Pref. southward to Kyushu along both coasts), 73-530 m deep.

Podocatactes hamifer: Sakai, 1936, p. 117, pl. 31, fig. 1- Japan.

Podocatactes hamifer: Sakai, 1939, p. 370, pl. 42, fig. 1-Sagami Bay.

Podocatactes hamifer: Sakai, 1965b, p. 109, pl. 50, fig. 2-Sagami Bay, 80-120m deep.

\section{Material examined:}

1 ovig. 우 (15.8 $\mathrm{mm}$ in breadth, eggs measure $1.2 \mathrm{~mm}$ in diameter), 1 우, ZLKU No. 12508 ;35¹6.1' N, 122” 51.5' E, 150 m deep ; Feb. 13, 1961; H. Yamashita leg.

\section{Distribution :}

This species is endemic in Japan; it is known from the Tsugaru Strait along both coasts southward to Kyushu. Its bathymetric range is from 73 to $530 \mathrm{~m}$.

\section{Family Portunidae}

\section{Parathranites orientalis (Miers, 1886)}

Lupocyclus (Parathranites) orientalis Miers, 1886, p. 186, pl. 17, fig. 1 -Kei Is. (5 $49^{\prime} 15^{\prime \prime} \mathrm{S}, 132$ " 14'15" E), 250 m deep ; Admiralty Is. (1" 54' S, $146 "$ 40" E), $270 \mathrm{~m}$ deep.

Parathranites orientalis : Alcook, 1899, p. 17-Off Malabar coast, 91-122 m deep, and off Coromandel coast, $59 \mathrm{~m}$ deep, India; Andaman Is.

Parathranites orientalis : Rathbun, 1911, p. 204-Salomon Bank, Chagos Arch., 100-200 m deep.

Parathranites orientalis: Yokoya, 1933, p. 178-Japan (several localities along Pacific coast from Suruga Bay southward to west of Sata-misaki, Kagoshima Pref.; near Koshiki-jima Is. and around Goto Is . ; west of Mikuni, Fukui Pref.), 115-300 m deep.

Parathranites orientalis: Sakai, 1936, p. 119, pl. 32, fig. 2-Japan.

Parathranites orientalis: Sakai, 1939, p. 376, pl. 43, fig. 2-Sagami Bay and Tosa Bay, Japan.

Parathranites orientalis : Barnard, 1950, p. 148, fig. 29, i-l-Madagascar.

Parathranites orientalis: Stephenson, 1961, p. 97, figs. 1, B, 2, H, pl. 1, fig. 2, pl. 4, B-Off Port Stephens, 225 m deep, N.S.W., Australia.

Parathranites orientalis: Sakai, 1965b, p. 113, pl. 51, fig. l-Sagami Bay, 80-120 m deep. 


\section{Material examined :}

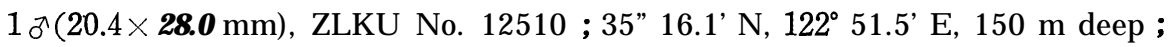
Feb. 13, 1961; H. Yamashita leg.

\section{Distribution :}

This species is known from Japan, the Admiralty and Kei Islands, and Australia, the Pacific Ocean, and from the Andamans, the coast of India and Madagascar, the Indian Ocean. In Japan it is known from the Sagami Bay southward to Kyushu, and off Fukui Prefecture, the Sea of Japan. The bathymetric range is from 80 to $300 \mathrm{~m}$.

\section{Macropipus corrugatus (Pennant, 1777)}

Portunus corrugatus : de Haan, 1835, p. 40-Japan.

Portunus strigilis: Stimpson, 1907, p. 74-Kagoshima Bay, Japan, $36 \mathrm{~m}$ deep.

Portunus corrugatus : Miers, 1879, p. 33-Goto Is., Japan ; 33” 12.5’ N, $129^{\circ} 5$ ' E, $16 \mathrm{~m}$ deep ; $32^{\circ} 49^{\prime} \mathrm{N}, 128^{\circ} 54^{\prime} \mathrm{E}, 20 \mathrm{~m}$ deep.

Portunus corrugatus : Miers, 1881, p. 219 - Senegambia.

Portunus corrugatus : Miers, 1886, p. 200-Azores, 90-162 m deep ; Cape Verde Is.; Port Phillip, $60 \mathrm{~m}$ deep, Vic., Australia ; off East Moncoerus I., $68 \mathrm{~m}$ deep, Bass Strait, Australia.

Portunus corrugatus : Ortmann, 1.893, p. 70-Mediterranean Sea ; Messina and Nizza, Sicily ; Tokyo and Kagoshima, Japan.

Liocarcinus strigilis : Rathbun, 1902, p. 25- Sagami Bay, Kii and Nagasaki, Japan.

Portunus subcorrugatus : Nobili, 1906, p. 186-Red Sea.

Portunus corrugatus : Borradaile, 1916, p. 97, fig. 9-Off New Zealand.

Liocarcinus strigilis : Parisi, 1916, p. 170-Sagami Bay, Japan.

Portunus corrugatus strigilis : Balss, 1922, p. 101-Sagami Bay and Suruga Bay, Japan ; Hongkong.

Portunus corrugatus : Palmer, 1927, p. 881, fig. 2-Plymouth, England.

Liocarcinus corrugatus : McNeil1 and Ward, 1930, p. 379-Off Botany Bay to Wata Mooli, $90 \mathrm{~m}$ deep, and off Green Cape, $72 \mathrm{~m}$ deep, N. S. W., Australia ; Mevagissey, England; Mediterranean Sea; Bay of Naples.

Portunus corrugatus strigilis: Yokoya, 1933, p. 173-Japan (several localities along Pacific coast from north of Inubo-zaki southward to Wakayama Pref.; near Tsushima I. ; off Tsubaki-zaki and Ryuhi-zaki, Aomori Pref., Sea of Japan), 51-146 $\mathrm{m}$ deep.

Portunus corrugatus strigilis : Sakai, 1934a, p. 301 -Nagasaki, Japan.

Portunus corrugatus strigilis : Sakai, 1939, p. 377, pl. 43, fig. 1- Tateyama Bay, Ise Bay and Hiroshima Pref., Japan.

Macropipus corrugatus : Stephenson and Campbell, 1960, p. 92, figs. 1, E, 2, G, pl. 2, fig. 4, pl. 5, G-Australia (Jervis Bay, Botany Bay, Green Cape and 
Gunnamatta Bay, $\mathbf{7 2 - 1 3 5} \mathrm{m}$ deep, N.S.W.; Port Phillip and Cape Everard, Vic.; Wingelass Bay, Tasmania).

Macropipus corrugatus : Miyake, 1961, p. 17\% Sea of Ariaké, Japan.

Macropipus corrugatus: Sakai, 1965b, p. 114, pl. 51, fig. 2-Sagami Bay, 35$120 \mathrm{~m}$ deep.

\section{Material examined :}

1 ð damaged, ZLKU No. 12511; 35” 16.1' N, 122 51.5’ E, 150 m deep; Feb. 13, 1961; H. Yamashita leg.

1 ovig. 우 (13.4 x $15.6 \mathrm{~mm}$ ), ZLKU No. 12598 ;32²4.8' N, 129” 24.7’ E, depth unknown; Oct. 24, 1962; H. Yamashita leg.

\section{Remarks :}

In the Japanese material the first male pleopod is so exactly agreeable with that of the Australian material represented by Stephenson and Campbell (1960, fig. 1, E and 2, G) that the institution of the subspecific status seems to be scarcely necessary.

\section{Distribution :}

This rather familier species may be widely distributed in the Indo-Pacific and European waters. In the Indo-Pacific waters it is known from Japan, New Zealand, Australia and the Red Sea, though some intervening localities are now unknown. Palmer (1927) gives its distribution as, "British Isles, France, Belgium, Mediterrancan, Adriatic, Canary Is. (Heller, 1862) ; Scotland to Cape Verde, Azores, and Canaries (Bouvier, 1922) ; Oran (Lucas, 1849) ; Red Sea (A. Milne Edwards, 1861) ; Senegambia (Miers, 1881) ; Senegambia to Sierra Leone (Balss, 1922) ; Japan (Miers, 1879) ; Victoria, Australia (Miers, 1886) ; New Zealand (Borradaile, 1916)."

\section{Charybdis (Gonioneptunus) bimaculata (Miers, 1886)}

Portunus (Thalamita) truncata : de Haan, 1835, p. 43, pl. 2, fig. 3, pl. 12, fig. 3-Japan.

Portunus (Charybdis) truncata var. : de Haan, 1837, p. 65, pl. 18, fig. 2-Japan. Goniosoma variegatus var. bimaculata Miers, 1886, p. 191, pl. 15, fig. 3-Kobe, Japan, $90 \mathrm{~m}$ deep.

Gonioneptunus subornatus Ortmann, 1893, p. 79, pl. 3, fig. 9-Tokyo Bay, Kanagawa, Kochi, Kagoshima, Nagasaki and Maizuru, Japan.

Charybdis (Gonioneptunus) truncata : Alcock, 1899, p. 67-Gulf of Martaban, 95$120 \mathrm{~m}$ deep.

Charybdis (Gonioneptunus) bimaculata : Alcock, 1899, p. 69-Palk Strait, Orissa coast, India. 
Gonioneptnus subornatus : Whitelegge, 1900, p. 156-Between Botany Bay and Wata Mooli, 90-128 m deep, N.S.W., Australia.

Charybdis subornata : Rathbun, 1902, p. 28-Kii and Hiroshima Pref., Japan.

Charybdis subornata : Parisi, 1916, p. 174-Tokyo Bay and Suruga Bay, Japan.

Charybdis (Gonioneptunus) subornata : Balss, 1922, p. 103-Sagami Bay, 130-150 $\mathrm{m}$ deep, and Kagoshima, Japan.

Charybdis (Gonioneptunus) bimaculata : Shen, 1932, p. 81, figs. 46, 47, pl. 4, fig. 3Shantung Penin., China.

Gonioneptunus whiteleggei Ward, 1933, p. 380, pl. 23, figs. 1, 2-Off Newcastle, N.S.W., Australia.

Charybdis (Gonioneptunus) subornata : Yokoya, 1933, p. 174-Japan (several localities along Pacific coast from near Shioya-zaki, Aomori Pref. southward to Kagoshima Pref. ; around Koshiki-jima Is. ; Sea of Japan northward to north of Oga, Aomori Pref.), 46-439 m deep.

Charybdis (Gonioneptunus) subornata : Sakai, 1934a, p. 302- Kagoshima, Japan.

Charybdis (Gonioneptunus) bimaculata : Shen, 1935, fig. 2, b-No new locality.

Charybdis (Gonioneptunus) subornata : Shen, 1935, fig. 2, a, c-No new locality.

Charybdis (Gonioneptunus) africana Shen, 1935, p. 405, figs. 1, 2, a-Off Great Fish

Point, 54m deep, and off Tugela River mouth, $1.13 \mathrm{~m}$ deep, S. Africa.

Charybdis bimaculata : Sakai, 1935, p. 75, fig. 8, c-No definite locality.

Charybdis bimacula ta : Sakai, 1936, p. 127, pl. 34, fig. 2-Japan.

Charybdis (Gonioneptunus) bi maculata : Leene, 1938, p. 126, figs. 70, 71-Tsingtao, China.

Gonioneptunus whiteleggei : Leene, 1938, p. 125-No new locality.

Charybdis (Gonioneptunus) africana : Leene, 1938, p. 129, figs. 72 , 73-No new locality.

Charybdis bimaculata : Sakai, 1939, p. 410, figs. 10, 11, pl. 45, fig. 3, pl. 82, fig. 2-Tanshui, Taiwan ; Inchon, Korea ; Japan (off Kinkazan, Tateyama Bay, Sagami Bay, Ise Bay, Osaka Bay, Nagasaki and Kagoshima Bay).

Charybdis (Gonioneptunus) bimaculata : Stephenson, Hudson and Campbell, 1957, p. 504, figs. 2, J, 3, K, pl. 3, fig. 4, H, 5, a-Warrior Reef, Queens., Watamooli, Newcastle, Pt. Perpendicular and Wreck Bay, N.S.W., Australia. Charybdis (Gonioneptunus) bimaculata : Stephenson, 1,961, p. 117-Off Barrow I. (19” 25' S, 116" 25' E) W. Australia.

Charybdis bimaculata : Miyake, 1961, p. 172-Sea of Ariaké, Japan.

Charybdis bimaculata : Sakai, 1965b, p. 120 , pl. 58, fig. 4-Sagami Bay, 50-85 m deep.

\section{Material examined :}

1 우 (13.2 mm in length), ZLKU No. 12512 ; definite locality not available, $0.1 \mathrm{~m}$ deep by larva net; May 3, 1967; Seikai Reg. Fish. Res. Lab. leg. 


\section{Distribution :}

This species is widely distributed from Japan southward to New South Wales, Australia, and across the Indian Ocean westward to thecoast of Africa. In Japan it is known northward to Shioya-zaki, Aomori Prefecture along the Pacific coast, and northward to north of Oga, Aomori Prefecture along the coast of the Sea of Japan. The bathymetric range is from 46 to $439 \mathrm{~m}$.

\section{Thalamita sp.}

\section{Description :}

Only a subadult female is available, of which the chelipeds and the ambulatory legs are all missing, and moreover the right anterolateral border is somewhat damaged. The carapace is covered with short hairs uniformly but rather sparingly, and provided with several plumose hairs on the ridges; the frontal ridges are represented by the low rounded elevations; the protogastrics are oblique, but represented by the granular elevations, while the mesogastrics are transverse and strongly developed, being interrupted at its middle portion; the epibranchial is strongly curved, and broadly interrupted by cervical grooves and medially; the prominent cardiac ridge is widely separated by the median interruption which is as broad as each lateral portion ; on either side of the cardiac ridge the short mesobranchials are present.

The front is four-lobed, but the lateral ones are shallowly concave near the lateral angles; each lobe is not convex, but a little arched, of which the lateral ones are placed at higher level: in the dorsal view the lateral lobes are twice as broad as the median ones, but in the frontal view the true median ones are as broad as the lateral ones.

The basal antenna1 segment bears no prominent ridge, but is provided with granules, of which the several are rather prominent.

The anterolateral teeth are five in number, of which the fourth is, however, rudimentary ; the first, the external orbital angle itself, is the most prominent and most strongly directed forward, while the other three are subequal.

\section{Material examined :}

1 우 subadult, (4.5 mm in length) ZLKU No. 12584 ; 25” 58’ N, 122³2' E, 103 m deep; Jun. 7, 1962; H. Yamashita leg.

\section{Remarks :}

According to the key given by Stephenson and Hudson (1957), this species 
is led to T.sexlobata Miers which is known from Tongatapu I., Australia, the Andamans, the Gulf of Manaar and the Persian Gulf. In the latter species, however, the mesogastric ridges are continuous across the mid line, and there are anterior mesobranchials. Though in the present specimen the cardiac ridge is interrupted medially, it is known in the latter species that the cardiac one is also sometimes interrupted. The present specimen may be close to T. sexlobata, but it is too young and incomplete to be given the specific name.

\section{Portunus gladiator Fabricius, 1789}

Portunus (Amphitrite) glaiator : de Haan, 1833, p. 39, pl. 1, fig. 5-Japan.

Nec Portunus (Amphitrite) gladiator : de Haan, 1837, p. 65, pl. 18, fig. $1(=P$. orbitospinis Rathbun) - Japan.

Neptunus gladiator: Richters, 1880 , p. 152-Mauritius.

Neptunus (Amphitrite) gladiator : Miers, 1886, p. 177-South of New Guinea (9 $\left.59^{\prime} \mathrm{S}, 129^{\circ} 42^{\prime} \mathrm{E}\right), 50 \mathrm{~m}$ deep.

Neptunus gladiator : de Man, 1887, p. 69-Owen I., Margui Arch.

Neptunus gladiator: Henderson, 1893, p. 367 - Ceylon ; Rameswaram and Madras, India; Gulf of Martaban.

Neptunus (Amphitrite) gladiator: Ortmann, 1893, p. 73-Tokyo Bay and Kochi, Japan.

Neptunus (Amphitrite) gladiator : Alcock, 1899, p. 35- Ceylon ; Madras and Sundarbuns, India ; Mergui Arch.

Portunus (Achebus) gladiator : Rathbun, 1910, p. 361-Gulf of Siam, 5-18 m deep.

Neptunus (Amphitrite) gladiator : Parisi, 1916, p. 173-Sagami Bay, Japan.

Neptunus (Amphitrite) gladiator: Sakai, 1934a, p. 303 - Nagasaki, Japan.

Neptunus (Amphitrite) gladiator : Sakai, 1936, p. 129, pl. 36, fig. 3-Japan.

Neptunus (Amphitrite) gladiator : Sakai, 1939, p. 390, fig. 5, a, pl. 47, fig. 3-Tateyama Bay, Sagami Bay, Ise Bay and Kii, Japan.

Portunus gladiator: Stephenson and Campbell, 1959, p. 110, fig. 2, J, 3, J, pl. 3, fig. 2, pl. 4, J, 5, J-Between Cape Jaubert and Wallal, $9 \mathrm{~m}$ deep, and between C. Bossut and Broome, $9 \mathrm{~m}$ deep, W. Australia.

Portunus gladiator: Miyake, 1961, p. 172-Sea of Ariaké, Japan.

Portunus gladiator: Sakai, 1965b, p. 118, pl. 57, fig. l-Sagami Bay, 10-60 m deep.

\section{Material examined :}

2 우우 (Largest 우, $20.6 \times 43.8 \mathrm{~mm}$ ), ZLKU No. 12513, and many juveniles; $31^{\prime \prime} 30^{\prime} \mathrm{N}, 123^{\circ} 6$ ' E, 0 m by larva net at night ; Jul. 21, 1962 ; H. Yamashita leg. 


\section{Distribution :}

This species ranges from Japan, China, Taiwan and the Gulf of Siam, the West Pacific, to Western Australia, and across the coast of India to Mauritius and the east coast of Africa.

\section{Family Xanthidae \\ Paratergatis longimanus Sakai, 1965}

Paratergatis Iongimanus Sakai, 1965a, p. 96, fig. l-Sagami Bay, Aichi Pref. and Tosa Bay, Japan, 60-120 m deep.

Paratergatis longimanus: Sakai, 1965b, p. 129, fig. 16, pl. 66, fig. 3-No new locality.

\section{Material examined}

1 ð $(5.9 \times 9.2 \mathrm{~mm})$, ZLKU No. 12515 ; 29” 30.7 ' N, 126” 31' E, $100 \mathrm{~m}$ deep, sandy bottom ; Jun. 27, 1962; H. Yamashita leg.

\section{Distribution :}

This species was originally described from the Sagami Bay, off Aichi Prefecture and the Tosa Bay at the depth of 60 to $120 \mathrm{~m}$.

\section{Nanocassiope granulipes (Sakai, 1939)}

Heteropanope granulipes Sakai, 1939, p. 546, fig. 59-Sagami Bay, Japan.

Heteropanope (?) granulipes : Serene, 1964, p. 185, fig. 1, pl. 6, A- Off Durban, S. Africa $\left(30^{\circ} 4^{\prime} 15^{\prime \prime} \mathrm{S}, 31^{\prime \prime} 30^{\prime \prime} \mathrm{E}\right), 100 \mathrm{~m}$ deep.

Micropanope granulipes : Sakai, 1965b, p 139, pl. 70, fig. 2-Sagami Bay, 75-120 $\mathrm{m}$ deep.

Nanocassiope granulipes : Guinot, 1967, p. 356, fig. 14-No new locality.

\section{Material examined:}

1 ( (2.9 $4.2 \mathrm{~mm})$, ZLKU No. $12516 ; 27^{\prime \prime} 16^{\prime} \mathrm{N}, 125$ ” 34.5 ' E, depth unknown ; Jun. 12, 1962; H. Yamashita leg.

\section{Remarks :}

This species was transferred to the present genus on account of having the characteristic first male pleopod which bears some undulating stout setae at the apex. Serène (1964) reported this species from South Africa and represented the first male pleopod, with which those of the Japanese specimens from the Sea of Ariaké examined are quite agreeable.

According to Sakai (1965), the carapace is $12 \mathrm{~mm}$ in length, and 20 $\mathrm{mm}$ in breadth, and furthermore it was noted that the original description was based upon an immature male $(4.4 \times 6.4 \mathrm{~mm})$. In the rather small 
materials examined including the specimens from the Sea of Ariaké, however, the pleopods of both sexes are well developed.

\section{Distribution :}

The type locality is the Sagami Bay, Japan. Though the intervening localities otherwise are unknown to date, it was recorded from off Durban, South Africa. The bathymetric range is from 30 to $1.20 \mathrm{~m}$.

\section{X antho cultripes Alcock, 1898}

Xantho (Lophoxanthus) scaberrimus var. cultripes Alcock, 1898, p. 117 - Singapore. Xantho reynaudii cultripes : Sakai, 1939, p. 461, pl. 90, fig. 2- Tosa Bay, Japan. Lophoxanthus reynaudii var. cultripes: Buitendijk, 1950, p. 77--Singapore.

\section{Material examined:}

1 خ infested by bopyrid (29.5x37.2 mm), 1 우 (27.9 $35.2 \mathrm{~mm})$, ZLKU No. $8180 ; 28^{\circ} 23^{\prime} \mathrm{N}, 122^{\circ} 4^{\prime} \mathrm{E}, 71 \mathrm{~m}$ deep; Mar. 19, 1957 ; H. Yamashita leg.

\section{Remarks :}

The present species is readily distinguished from $\mathrm{X}$. reynaudi (H. Milne Edwards) by the following respects. (1) The squamose granules on the carapace is less prominent at its middle portion. (2) The lateral angle of the front is strongly produced. (3) Four anterolateral teeth of the carapace are low and sometimes obscure. (4) In the ambulatory legs each crest of the upper borders of the merus and propodus is entire, and the upper surfaces of those segments are provided only with minute granules.

\section{Distribution :}

This species has been known from Singapore and the Tosa Bay, Japan at the considerable depth.

\section{Liomera boninensis (Odhner, 1925)}

\section{(Fig. 1)}

Carpilodes lophopus var. boninensis Odhner, 1925, p. 18, pl.1, fig. 4.3 - Bonin Is, 145-150 m deep; Sagami Bay, 300 m deep.

Carpilodes lophopus boninensis : Sakai, 1935, p. 78, fig. 12 --Sagami Bay, $45 \mathrm{~m}$ deep ; East China Sea (28” 28' N, 126” '2' E).

Carpilodes lophopus boninensis: Sakai, 1936, p. 158, pl. 47, fig. 4-Japan.

Carpilodes lophopus boninesis: Sakai, 1939, p. 472, pl. 60, fig. 6-Sagami Bay.

Liomera lophopa boninensis: Sakai, 1965b, p. 143, pl. 71, fig. 4-Sagami Bay, 30$58 \mathrm{~m}$ deep. 


\section{Material examined :}

1 우, ZLKU No. 9772; 26” 53.3’ N, 123” 0.5’ E, 120-122 m deep ; Feb. 21, 1961; H. Yamashita leg.

$1 \sigma^{\star}$, ZLKU No. 12517 ; $27^{\prime \prime} 55^{\prime} \mathrm{N}, 123^{\circ} 35^{\prime} \mathrm{E}$, depth unknown; Apr. 6, 1962 ; H. Yamashita leg.

$1 \delta^{\prime}(7.3 \times 10.5 \mathrm{~mm})$, ZLKU No. $12518 ; 28^{\circ} 36.6^{\prime} \mathrm{N}, 124^{\prime \prime} 40^{\prime} \mathrm{E}, 84 \mathrm{~m}$ deep; May 30, 1962; H. Yamashita leg.

1 ㅇ (6.7 x9.9 mm), ZLKU No. 12519 ; 25” "58’ N, 122 32' E, 103 m deep ; Jun. 7, 1962; H. Yamashita leg.

1 우, ZLKU No. 12520 ;31³1.7’ N, 127” 27.4' E, 128 m deep; Jul. 9, 1962 : H. Yamashita leg.

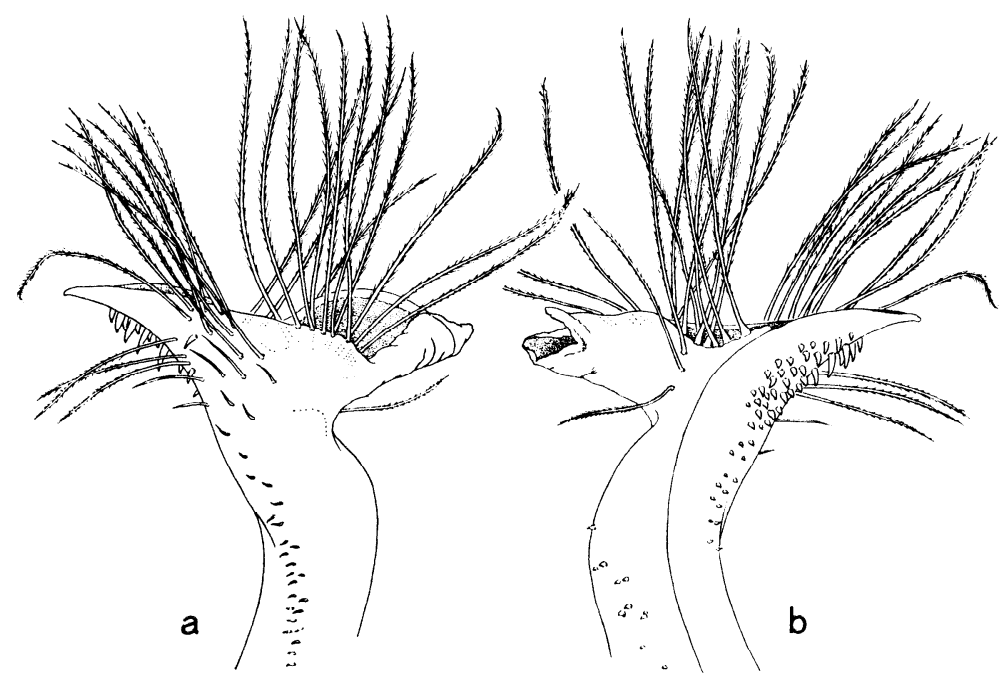

Fig. 1. Liomera boninensis (Odhner). a, Distal portion of first pleopod of male $(7.3 \times 10.5 \mathrm{~mm})$ in sternal view, $\mathrm{X} 40$; $\mathrm{b}$, the same in abdominal view, $\mathrm{X} 40$.

\section{Remarks :}

This species is most characterized by the areolation of the carapace and the armature of the anterolateral borders; $2 \mathrm{M}$ is convex and divided into two areolets by the longitudinal narrow furrow; the anterolateral border is cut into four teeth, of which the posterior two teeth are sharp and upturned. The first male pleopod is very characteristic and readily distinguished from those of the other members of the genus as repesented in Fig. 1.

\section{Distribution :}

This species is known from the Bonin Islands, the East China Sea and the Sagami Bay at the depth of 30 to $300 \mathrm{~m}$. 


\section{Actaea savignyi (H. Milne Edwards, 1834)}

Cancer (Actaea) granulatus: de Haan, 1833, p. 18-No new locality. Actaea carcharias: White, 1848, p. 284-Swan River, W. Australia. Actaea granulata : A. Milne Edwards, 1865, p. 275-Red Sea ; Mozambique ; Mauritius ; Port Jackson, N.S.W., Australia.

Actaea carcharias : A. Milne Edwards, 1865, p. 276-No new locality. Actaea granulata: A. Milne Edwards, 1873a, p. 192-New Caledonia.

Euxanthodes granulata : Paulson, 1961 (1875), p. 42, pl. 6, fig. 3-Red Sea. Actaea Savignii : Hilgendorf, 1878, p. 787 -Mozambique.

Actaea granulata : Miers, 1879, p. 30-No definite locality.

Actaea granulata : Haswell, 1882, p. 44-Port Denison, Queens., and Port Stephens and Port Jackson, N.S.W., Australia.

Actaea granulata: Miers, 1886, p. 120-Off Cape York, Torres Strait, $15 \mathrm{~m}$ deep. Actaea granulata : Henderson, 1893, p. 356-Tuticorin, Rameswaram and Madras, India.

Actaea granulata : Alcock, 1898, p. 151-Persian Gulf ; Karachi ; Gamjam Coast, India ; Ceylon ; Mergui Arch. ; Strait of Malacca ; Hongkong ; Australia Actaea granulata : de Man, 1902, p. 617-Ternate, Halmahera.

Actaea granulata : Nobili, 1906, p. 261- Beilul, Red Sea, 8 m deep.

Actaea pura: Stimpson, 1907, p. 44, pl. 5, fig. 7-Northern China Sea ; Hongkong ; Port Jackson, N.S.W., Australia.

Actaea savignyi : Rathbun, 1911, p. 221-Cargados Carajos Is., near Mauritius, 50-54 m deep ; Saya de Malha Bank, $99 \mathrm{~m}$ deep; Amirante Is., $52 \mathrm{~m}$ deep ; Seychelles, 56-61 m deep.

Actäa (Euxanthodes) Savignyi : Klunzinger, 1913, p. 194, pl. 1, fig. 6, pl. 3, fig. 4, pl. 6, fig. 8-Suez, Red Sea.

Actaea savignyi pura: Balss, 1922, p. 122-Sagami Bay, 20-300 m deep, and Nagasaki, Japan.

Actaea savignyi : Odhner, 1925, p. 52-Suez, Sinai and Djibuti, Red Sea ; Mozambique ; Shark Bay, W. Australia ; North Borneo ; Kei Is., 40-50 m deep ; Sulu Is., 36-54 m deep ; New Caledonia ; Hongkong ; Macclesfield Bank ; Formosa Strait, $45 \mathrm{~m}$ deep; S. W. Japan (32“ $\left.12^{\prime} \mathrm{N}, 128^{\circ} 15^{\prime} \mathrm{E}\right), 144 \mathrm{~m}$ deep: Sagami Bay, Japan.

Actaea savignyi pura: Yokoya, 1933, p. 188-Near Inubo-zaki, Japan, 18 m deep. Actaea savignyi pura: Sakai, 1934a, p. 309-Nagasaki, Japan.

Actaea granulata carcharias : Sakai, 1934a, p. 309-Nagasaki.

Actaea savignyi : Sakai, 1936, p. 160, pl. 48, fig. 2-Japan.

Actaeu savignyi : Sakai, 1939, p. 485, fig. 37, pl. 61, fig. 2-Tateyama Bay and Izu, Japan.

Actaea savignyi : Stephensen, 1945, p. 151, fig. 38, C- Persian Gulf, 11-17 m deep. 
Actaea savignyi : Barnard, 1950, p. 231, fig. 43, b, c-Off Umhloti River and Umtwalumi River, $45 \mathrm{~m}$ deep, and Delagoa Bay, S. Africa. Actaea savignyi : Miyake, 1961, p. 173-Sea of Ariaké, Japan.

Actaea savignyi : Sakai, 1965b, p. 145, pl. 72, fig. 2--Sagami Bay, Japan, from rocky beach to $15 \mathrm{rn}$ deep.

\section{Material examined:}

1 ovig. 우 (15x 18 mm), ZLKU No. 571; 29” N, 126“ 30' E, depth unknown; Jul. 10, 1954; H. Yamashita leg.

\section{Distribution :}

This species is very widely distributed in the whole Indo-West Pacific waters both geographically and bathymetrically. It ranges from Japan southward to New Caledonia and Australia, and across the Indian Ocean westward to the Red Sea and South Africa. Its bathymetric range is from the rocky shore to $300 \mathrm{~m}$.

\section{Calvactaea tumida Ward, 1933}

(Fig. 2, a)

Calvactaea tumida Ward, 1933, p. 384, pl. 23, fig. 9-Port Jackson, and Cape Hawke, $90 \mathrm{~m}$ deep, N.S.W., Australia.

Calvactaea tumida: Sakai, 1939, p. 497, fig. 9, pl. 94, fig. 7-Sagami Bay, Izu and Kii, Japan,

Calvactaea tumida: Sakai, 1965b, p. 148, fig. 39, pl. 73, fig. 3-Sagami Bay, 25$30 \mathrm{~m}$ deep.

\section{Material examined:}

1 ð (8.7 x $10.1 \mathrm{~mm})$, ZLKU No. 12528 ; 26” 5’ N, 122” 55.5’ E, -26” 9.8’ N, 123 1.9’ E, 110-111m deep; Dec. 9, 1967; H. Yamashita leg.

\section{Distribution :}

It is peculiar that this characteristic species has been known only from Aus $t$ r-alia and Japan. It was remarked by the original author that the species occurs associated with a soft coral, and that the holotype was taken from a cavity within the body wall of the coral. In Japan it is known as a commensal with alcyonarians and ranges from the Sagami Bay southward to the Kii Peninsula. 


\section{Actumnus forficigerus (Stimpson, 1858)}

(Fig. 2, b-d)

Pilumnus forficigerus: Stimpson, 1907, p. 68, pl. 8, figs. 6, 6a-Off east coast of Amami-Oshima I., $54 \mathrm{~m}$ deep.

Actumnus forficigerus : Balss, 1922, $\mathrm{p}$. 119 - Bingo, Japan.

Actumnus forficigerus : Sakai, 1939, p. 528 , fig. 51 , b, pl. 99 , fig. 4 Sagami Bay, Japan.

Actumnus forficigerus : Sakai, 1965b, p. 155 , pl. 76 , fig. 4 - Sagami Bay, 35-85 m deep.

\section{Material examined:}

1 ð , ZLKU No. 12521; 30” 15.2' N, 127'26.4' E, 121 m deep; Jun. 11, 1963; H. Yamashita leg.

2 ð (Largest ๙ ZLKU No. 12522 ; 28” 44.7’ E, $124^{\circ}$ 51.7’ E, 92 m deep ; Jun. 13, 1963 ; H. Yamashita leg.

\section{Remarks :}

This species is closely related to A. squamosus (de Haan), but readily separated from it by the features that the carapace is covered with a short velvety tomentum mixed with long silky hairs instead of plumose ones, and that the granules on the chelipeds are not squamiform. The majority of those granules on the palm and carpus of the chelipeds are tipped each with a yellowish, semitransparent procurved spinule.

\section{Distribution :}

This species is restricted to the Japanese waters; it has hitherto

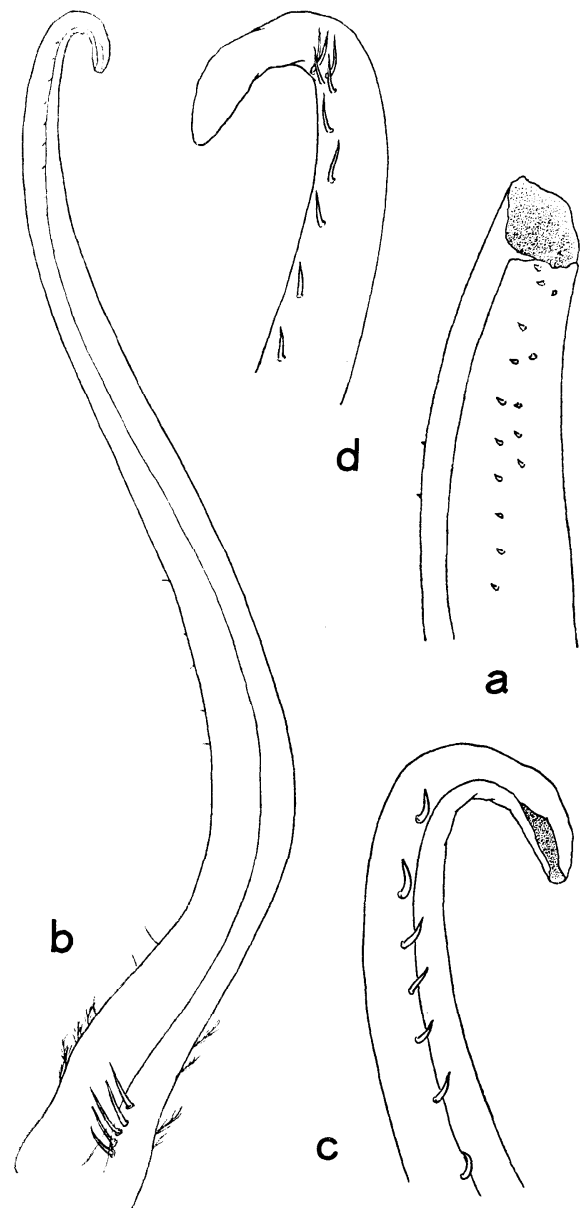

Fig. 2. Calvactaea tumida Ward. a, Distal portion of first pleopod of male $(8.7 \times$ $10.1 \mathrm{~mm})$ in adbominal view, $\times 50$.

Actumnus forficigerus (Stimpson). b, First pleopod of male $(5.2 \times 7.0 \mathrm{~mm})$ in abdominal view, $\mathrm{x} 41.5$; $\mathrm{c}$, distal portion of the same, $\times 100$; $d$, the same in sternal view, $\times 100$. 
been known from the Sagami Bay, Hiroshima Prefecture and Amami-Oshima Island. The bathymetric range is from 35 to $121 \mathrm{~m}$.

\section{Glabropilumnus sodalis (Alcock, 1898), new comb.}

(Fig. 3, Pl. 6, C, D)

Liomera (?) sodalis Alcock, 1898, p. 88 - Off south-east corner of Ceylon, $32 \mathrm{~m}$ deep.-Illust. 2001. Invest., 1899, pl. 36, fig. 5.

Liomera spinipes Borradaile, 1902, p. 253, fig. 52-Maldive Is., $54 \mathrm{~m}$ deep.

Pilumnus (3) sodalis: Odhner, 1925, p. 26-Bonin Is., 180-210 m deep.

Pilumnus sodalis: Sakai, 1939, p. 538-No new locality.

\section{Description :}

The carapace is very broad and strongly convex fore and aft; the surface is entirely smooth and ivory-like without any indication of the regions. The front is nearly perpendicularly deflexed so as to conceal the true border, and bears a small but V-shaped median sinus; the frontal lateral angle is somewhat angular, but not prominent, and is separated by a shallow indistinct depression from the supraorbital angle which is also not prominent. The orbit is somewhat ventral; its subraorbital border is weakly sinuate and minutely granulated laterally, but is entire; the external angle is not produced at all, and the infraorbital border is also minutely granulated and rounded near and at its inner angle. The antennule is folded obliquely ; its peduncle is short and stout; a curved crest is present at the lower border of the fossa. The basal antenna1 segment, which is truely the second, is short and not quite reached the front; its outer angle is slightly produced and protruded obliquely-forward; the second and third segments are subequal in length, but the former is stouter; the second is hardly reached the short ventral prolongation of the front, and the third is raised just to the supraorbital angle; the antenna1 flagellum is fine and slightly longer than the major diameter of the orbit.

The anterolateral and posterolateral borders are not distinctly delimited. The anterolateral portion is arched and bordered with a thick blunt crest ; otherwise it bears two very indistinct depressions, so that it is composed of three low lobes. The posterolateral portion is strongly convergent and concave dorsally.

The chelipeds are heavy and unequal in both sexes. The merus is short, and its upper border is strongly crested; the crest bears minute interruptions along the whole length, and a subterminal larger one. In the smaller specimen the outer surface of the larger carpus is entirely smooth, while that of the smaller carpus is thickly covered with small conical granules, of which those near the distal end are more prominent ; in the larger specimens the smaller carpus is entirely smooth like the larger one; the inner 
angle of each carpus is produced in a blunt tooth which is not conical, but ridge-like, and is provided with some indistinct granules. In the larger specimens the larger palm is entirely smooth, glabrous and devoid of hairs, while the smaller palm is thickly covered with conical granules interspaced with rather sparse short hairs; those granules are so thick and somewhat squamiform that they are not arranged in longitudinal rows ; in the smaller specimen the larger palm is also entirely covered with granules which are less prominent than those on the smaller palm, and the hairs are very sparse. In both chelae the fingers are stout and high; they are somewhat similar in both chelae, but in the smaller chela the proximal halves of the fingers are occupied with granules, the longitudinal furrows are much prominent and the teeth are sharper.

The ambulatory legs are comparatively slender. The merus is armed with a row of minute granules on the upper and lower borders respectively, and provided with very sparse short hairs. The carpus and propodus are armed with many conical granules of good size on and near the upper borders and provided with long silky hairs mostly on the upper borders; in the last pair those segments are covered with minute granules on the upper surf aces. The dactylus is armed with several spinules on the upper border, and covered with dense silky hairs. The male abdomen is narrow, and the first male pleopod is similar to those of the members of the genus Pilumnus.

\section{Material examined :}

1 Ђ (7.2 x $10.6 \mathrm{~mm}), 1$ ovig. 우(6.6 x $10.2 \mathrm{~mm})$, ZLKU No. 12524 ; off Chilung, Taiwan, depth unknown ; Jul. 25-Aug. 18, 1953 ; Seikai Reg. Fish. Res. Lab. leg.

1 ovig. 우 (9.2 x $14.6 \mathrm{~mm})$, ZLKU No. 12526 ; 27” 30.7’ N, 122” 29.9’ E, 90 m deep; Jun. 20, 1964; H. Yamashita leg.

1 ovig. 우 (6.7 x $10.4 \mathrm{~mm})$, ZLKU No. 12585 ; definite locarlity and depth not available; Jun. 9, 1962; H. Yamashita leg.

\section{Remarks :}

The present specimens are well agreeable with Alcock's (1898) and Borradaile's (1902) descriptions except for some variations. In the male specimen examined the front is not so deflexed that the median $\mathrm{V}$-shaped sinus is visible from above (Fig. 3, a). In the largest specimen that is ovigerous, the anterolateral border of the carapace is nearly entire, bearing no shallow depression. It is apparent that as mentioned before in the larger specimens the granules on the larger palm is worn out to be glabrous.

Odhner (1925) has done right in referring this species to the genus Pilumnus with some question on account of the formation of the front and the shape of the chelipeds. In addition, here it is remarked that the male 
abdomen is composed of seven distinct segments, the first male pleopod is somewhat Pilumnus-type, and the armatures of the ambulatory legs are similar to those of the genus Pilumnus. This species is, however, transferred mainly on account of the glabrous carapace and the shape of the anterolateral border to the genus Glabropilumnus which was established by Balss (1932) and closely related to the genus Pilumnus. In the genus Glabropilumnus this species is most close to G. seminudus (Miers) in the general contour of the carapace. In the latter species, however, the front and the anterolateral regions are covered with a band of close-set pubescence, and

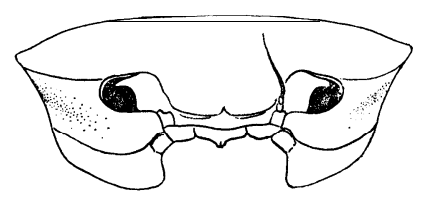

C
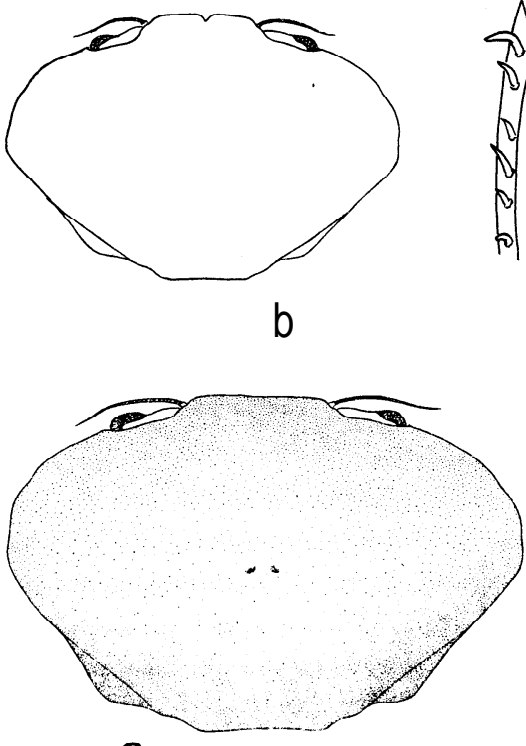

a
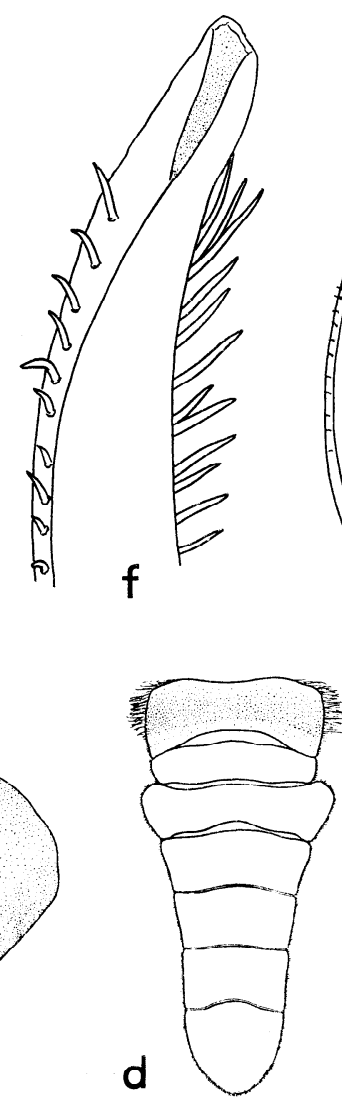

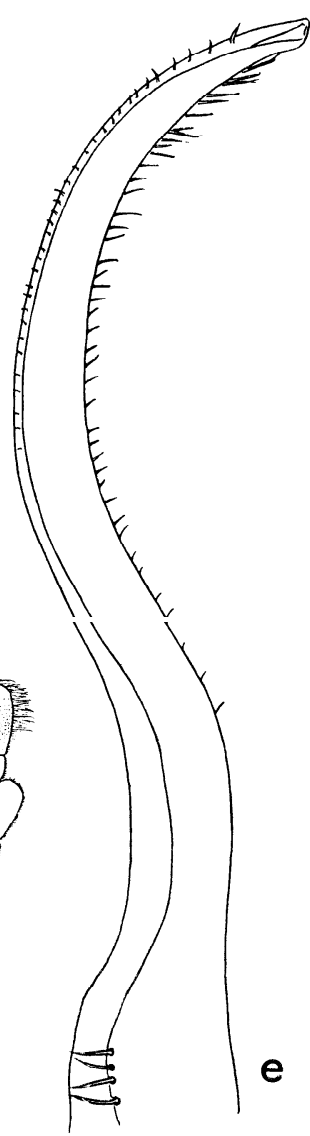

Fig. 3. Glabropilumnus sodalis (Alcock), a, Carapace of ovigerous female $(6.7 \mathrm{X} 10.4 \mathrm{~mm}), \mathrm{X} 5 ; \mathrm{b}$, carapace of male $(7.2 \times 10.6 \mathrm{~mm}), \times$ 3.8 ; c, the same in frontal view, X3.8; $\mathrm{d}$, abdomen of the same male, X7.5 ; e, first pleopod of the same male in abdominal view, $\mathrm{X}$ 41.5 ; f, distal portion of the same. X100. 
the chelipeds are also covered with similar pubescence. In the type of the genus, G. disper (Dana), the carapace and chelipeds are enitrely naked and glabrous, but the outline of the carapace is different from that of this species.

\section{Colour and Habitat :}

In the present specimens in alcohol the carapace, chelipeds and ambulatory legs, even the fingers, are entirely ivory-white. The cornea is not black, but yellowish. The colour in spirit and the habitat is remarked by Alcock as follows. "It is of the same blotchy orange and reddish colour as that of a species of Solenocaulon, in the hollow stem of which the crab was fonud." Of the material examined a male and an ovigerous female (No. 12524) were found in the hollow stem of a gorgonarian, Solenocaulon chinense Kükenthal like the case described by Alcock. In the stem two alpheid shrimps, Synalpheus trispinosus de Man and S. nilandensis Coutière, and a galatheid, Galathea balssi Miyake et Baba were also found together with.

\section{Distribution :}

This species has hitherto been known from off Ceylon and the Maldive Islands, the Indian Ocean and the Bonin Islands, the West Pacific. Its bathymetric range is from 32 to $210 \mathrm{~m}$.

\section{Ralumia balssi Sakai, 1935}

(Fig. 4)

Ralumia balssi Sakai, 1935, p. 79, fig. 13, pl. 7, fig. 4-Sagami Bay, Japan.

Ralumia balssi: Sakai, 1936, p. 173, pl. 52, fig. 4-Japan.

Ralumia balssi: Sakai, 1939, p. 550, fig. 62, pl. 55, fig. 4- Sagami Bay.

Ralumia balssi: Sakai, 1965b, p. 161, pl. 80, fig. 2-Sagami Bay, 35-85 $\mathrm{m}$ deep.

\section{Material examined :}

1 o $^{\Uparrow}(6.0 \times 6.2 \mathrm{~mm})$, ZLKU No. 12527; 34" 0.7' N, 129" 19.4' E, 110 m deep; Jun. 20, 1964; H. Yamashita leg.

\section{Remarks :}

This characteristic and rare species was well described and figured by Sakai (1935, 1936, 1939, 1965b).

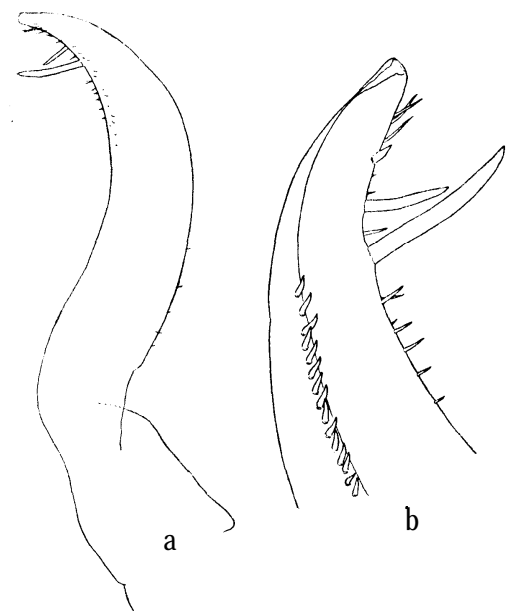

Fig. 4. Ralumia balssi Sakai. a, First pleopod of male (6. 0X6. $2 \mathrm{~mm}$ ) in sternal view, $\times 28$; $b$, distal portion of the same in abdominal view, $\mathrm{X} 67$. 
The first male pleopod is somewhat like that of Calmania prima Laurie, showing the close relationship of those two genera.

\section{Distribution :}

This species has hitherto been known only from the Sagami Bay, Japan. The bathymetric range is from 35 to $110 \mathrm{~m}$.

\section{Family Goneplacidae}

\section{Carcinoplax longimanus (de Haan, 1835)}

(Fig. 5, a-e)

Cancer (C urtonotus) Zongimanus de Haan, 1835, p. 50. pl. 6, fig. 1-Japan.

Carcinoplax longimana: Ortmann, 1894, p. 688 - Sagami Bay and Nagasaki, Japan.

Carcinoplax longimanus : Alcock, 1900, p. 303-Gulf of Martaban and Andaman Sea, 95 and $108 \mathrm{~m}$ deep.

Carcinoplax longimana: Doflein, 1902, p. 662-Sagami Bay, Japan.

Carcinoplax Zongimanus japonicus : Doflein, 1904, p. 115, pl. 36-Japan.

Carcinoplax Iongimanus : Parisi, 1918, p. 90-Sagami Bay and Hakodate, Japan ; China Sea.

Carcinoplax Zongimanus : Balss, 1922, p. 135-Sagami Bay, 100-150 m deep, and Kagoshima, Japan.

Carcinoplax longimanus : Yokoya, 1933, p. 190-North-west of Niigata, $72 \mathrm{~m}$ deep, Sea of Japan.

Carcinoplax longimanus : Sakai, 1934a, p. 311-Nagasaki, Japan.

Carcinoplax Iongimanus : Sakai, 1936, p. 181, pl. 53, fig. 3-Japan.

Pilumnoplax inaequalis : Sakai, 1936, p. 183, pl. 54, fig. l-Japan

Carcinoplax longimanus : Sakai, 1939, p. 555, pl. 101-Sagami Bay, Ise Bay, Kii and Tosa Bay, Japan.

Carcinoplax longimanus : Barnard, 1950, p. 287, fig. 53, g, h-Off Kowie, Algoa Bay to off Tugela River mouth and Natal, S. Africa, 72-235 m deep.

Carcinoplax longimanus : Sakai, 1965b, p. 166, pl. 81-Sagami Bay, 30-80m deep.

\section{Material examined :}

2 Ђోઠ઼, 3 우우 (Largest?, 36.4x47.3 mm), ZLKU No. 888 ; definite locality unknown, 50 m deep, sandy mud bottom; Jul. 17-Sept. 2, 1953 ; H. Maëda leg.

\section{Remarks :}

According to Barnard (1950), the institution of a subspecific name C. longimanus indicus Doflein seems scarcely necessary in view of the growth-changes. For the further research on this matter the first and second male pleo- 
pods are represented in Fig. 5, a-e; the second male pleopod is subfiliform and longer than the first one, its tip being nearly truncated and bearing two spiny processes. The changes of the chelipeds following the growth of the carapace were dealt with by Yamashita (1965) based on the materials from the East China Sea.

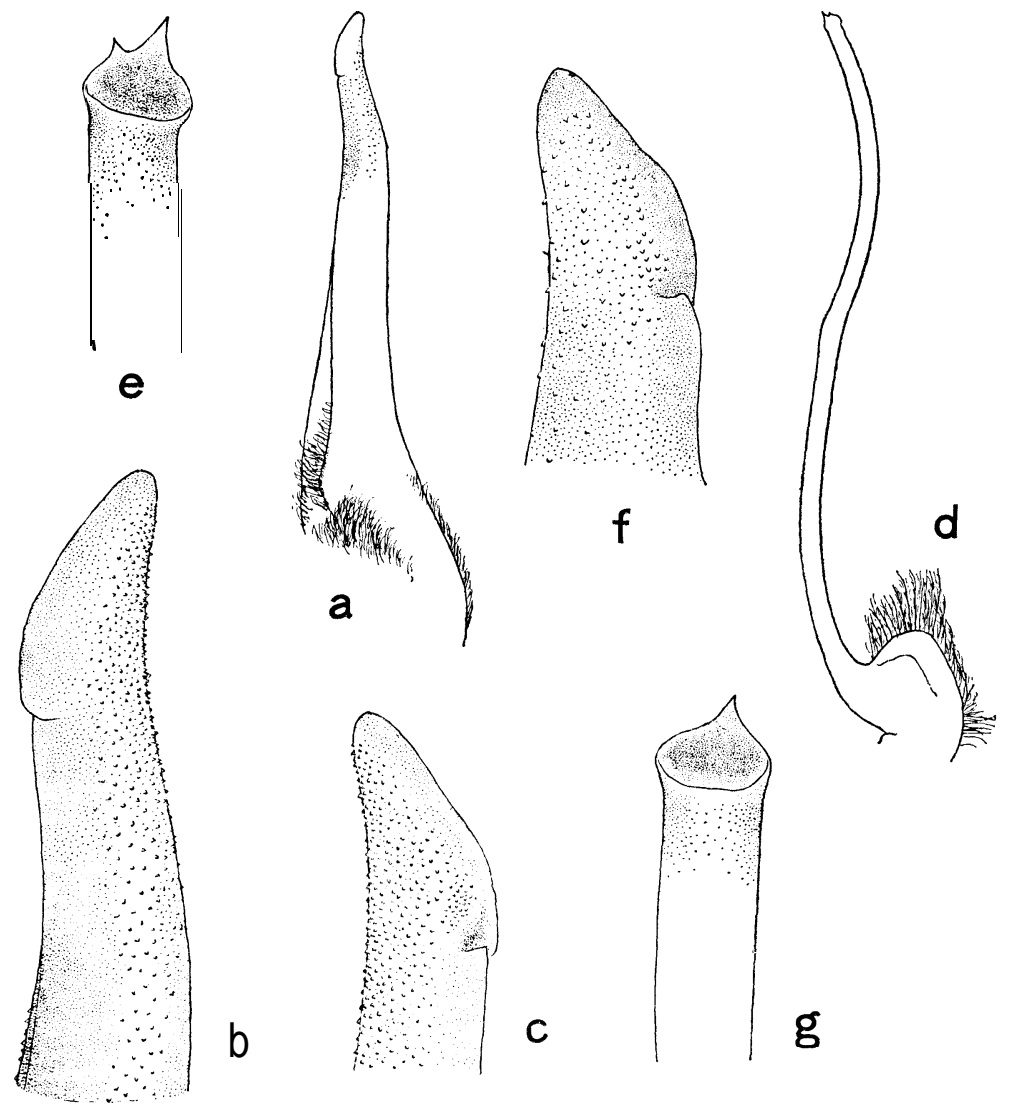

Fig. 5. Carcinoplax longimanus (de Haan). a, First pleopod of male $(42.4 \times 55.2 \mathrm{~mm})$ in abdominal view, $\mathrm{x} 3.8$; $\mathrm{b}$, distal portion of the same, $\times 15 ; c$, the same in sternal view, X15; d, second pleopod of the same male in abdominal view, $\times 3.8$; e, distal portion of the same in sternal view, $\times 20$.

Carcinoplax vestita (de Haan). f, Distal portion of first pleopod of male $(17.0 \times 24.3 \mathrm{~mm})$ in sternal view, X45; g, distal portion of second pleopod of the same male in sternal view, $\times 60$. 


\section{Distribution :}

This species ranges from Japan through the China Sea, the Gulf of Martaban and the Andaman Sea to South Africa. In Japan it is commonly found from Hakodate southward to Kyushu. The bathymetric range is usually from 30 to $235 \mathrm{~m}$. Doflein (1904) recorded four young specimens as C. longimanus indicus from Great Nicobar Island at the depth of $752 \mathrm{~m}$.

\section{Carcinoplax vestita (de Haan, 1835)}

(Fig. $5, \mathrm{f}, \mathrm{g}$ )

Cancer (Curtonotus) vestitus de Haan, 1835, p. 51, pl. 5, fig 3-Japan.

Pilumnoplax vestita : Ortmann, 1894, p. 687-Tokyo Bay and Maizuru, Japan.

Carcinoplax vestita : Rathbun, 1902, p. 24-Kii, Japan.

Carcinoplax vestitus: Parisi, 1918, p. 91-Sagami Bay and Tokyo, Japan.

Pilumnoplax vestitus: Balss, 1922, p. 136-Sagami Bay, $110 \mathrm{~m}$ deep, Tokyo Bay, $45 \mathrm{~m}$ deep, and Tsushima I., Japan.

Carcinoplax vestita : Shen, 1932, p. 110, figs. 63-65, pl. 5, fig. l-Shantung Penin., China.

Pilumnoplax vestita : Yokoya, 1933, p. 191-West of Iki I., off Niigata Pref. and south of Oga, Aomori Pref., Sea of Japan, 51-72 m deep.

Pilumnoplax vestita : Sakai, 1934a, p. 312 -Nagasaki, Japan.

Pilumnoplax vestita : Sakai, 1936, p. 182, fig. 93-Japan.

Carcinoplax vestitus : Sakai, 1939, p. 557, fig. 64, pl. 66, fig. 5-Tateyama Bay, Tokyo Bay, Ise Bay, and Hiroshima Pref., Japan.

Carcinoplax vestita : Barnard, 1950, p. 288-No new locality.

Carcinoplax vestitus : Sakai, 1965b, p. 167, pl. 83, fig. 2-Sagami Bay, 35-85 m deep.

\section{Material examined:}

1 ð (17.0 x24.3 mm), ZLKU No. 893; definite locality unknown, $50 \mathrm{~m}$ deep, sandy mud bottom: Aug. 25-Sept. 2, 1953; H. Maëda leg.

\section{Remarks :}

The present species is very characteristic in the soft dense hairs on the carapace, chelipeds and ambulatory legs, by which it is readily distinguished from the congeners. The distal parts of the first and second male pleopds are represented in Fig. 5, f, g; they are closely allied to those of C. longimauus being only slightly different at their tips.

\section{Distribution :}

This species is known from Japan, North China and Australia. In Japan it is recorded from the Sagami Bay southward to Kyushu along the Pacific 
coast, and along the Sea of Japan northward to south of Oga. Its bathymetric range is from 35 to $110 \mathrm{~m}$.

\section{Pilumnoplax sp.}

(Fig. 6)

\section{Description :}

The carapace is narrow and evenly convex antero-posteriorly ; the dorsal surface is very faintly divided into regions and glabrous to the naked eye, but is provided with thick microscopical granules and sparse short hairs. The front is produced and truncated, being slightly less than half the breadth of the carapace; its lateral angle is not produced in a tooth and is separated from the less prominent supraorbital angle. The supraorbital border is generally concave, bearing a faint interruption at the middle ; the external orbital angle is rather produced, but not spine-tipped; the infraorbital border is raised, of which the inner angle is produced and subacute, its inner extremity being not contact with the antenna1 basal segment; the flagellum is about twice as long as the major diameter of the orbit; the eye is very expanded.

The anterolateral border of the carapace is armed with two spinetipped subequal teeth behind the external orbital tooth ; the first is directed obliquely-forward, while the second is directed somewhat upward and also obliquely-f orward. The posterolateral border is only slightly inclined, its dorsal surface being shallowly concave and granulated; the posterior border is rather prominently concave.

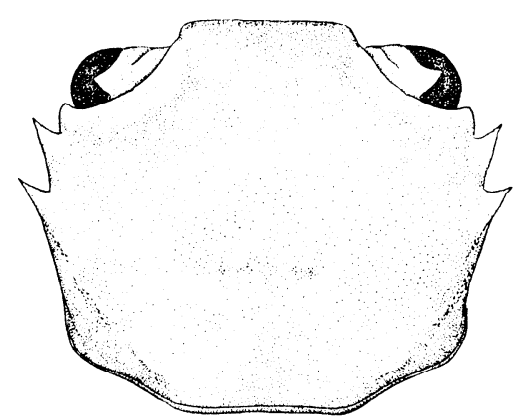

Fig. 6. Pilumnoplax sp. Carapace, $\times 12.5$

The chelipeds are thickly covered with minute granules. The merus bears a granular prominence at the middle portion of its upper border. The carpus is armed with a prominent spine-tipped tooth at its inner angle and with a spine at its outer angle. The palm is unarmed at all except for those thick granules. The fingers are longer than the palm, being crossed at the tips each other. In the last pair of the ambulatory legs the propodus is more or less depressed, its lower border being fringed with a row of long hairs unlike the preceding segments.

\section{Material examined :}

1 ð subadult ( 3.6 x $4.2 \mathrm{~mm}$ ), ZLKU No. 12529 ; 34” 0.7’ N, $129^{\circ} 19.4^{\prime} \mathrm{E}, 110 \mathrm{~m}$ deep; Jun. 20, 1964; H. Yamashita leg. 


\section{Remarks :}

The present material is apparently subadult, and the second pleopod is as long as the first one. Though many characters are close to those of the genus Carcinoplax, this material seems to be not the young of that genus, but referred to the present genus by bearing less convex carapace, the truncated but produced front and the large eye. In the present genus this species is close to $P$. glaberima Ortmann which was questionably thought to be the young form of Carcinoplaxlongimanus (de Haan) by Sakai (1965b). In that species, however, it is said that in the palm an obtuse tubercle is present at the middle portion of the inner surface. In P. glaberrima Yokoya (1933) noted that the specimens from the numerous localities around Japan are small in size, but some females are larger than the others.

\section{Goneplax renoculis Rathbun, 1914}

(Fig. 8, c-e)

Goneplax renoculis Kathbun, 1914, p. 145-Malavatuan I., off southern Luzon, Philippines, 140-180 $\mathrm{m}$ deep.

Goneplax renoculis : Yokoya, 1933, p.196-Japan (many localities along Pacific coast from south of Inubo-zaki southward to off Miyazaki Pref. ; around Goto Is. and Tsushima I. ; Sea of Japan northward to Kyo-gasaki, near Wakasa Bay), 101-172 m deep.

Goneplax renoculis : Sakai, 1936, p. 186, pl. 54, fig. 4-Japan.

Goneplax renoculis : Sakai, 1939, p. 563, pl. 67, fig. 4-Sagami Bay and Kumanonada, Japan.

Goneplax renoculis : Sakai, 1965b, p. 169, pl. 84, fig. 2-Sagami Bay, 65-85 m deep.

\section{Material examined:}

1 ॐ (5.2×7.3 mm), 1 우 (6.2 × $8.9 \mathrm{~mm})$, ZLKU No. $12530 ; 32$ ” 36.7' N, 127” 42.6' E, $145 \mathrm{~m}$ deep ; Jun. 17, 1964 ; H. Yamashita leg.

1 ॐ, ZLKU No. 12532 ; 29” 55.5’ N, 127” 22.9’ E, 126 m deep; Dec. 5, 1967; H. Yamashita leg.

1 우, ZLKU No. 12586 ; 26” 5' N, 122” 55' E- 26 9.8’ N, 123“ 1.9’ E, 110-111 m deep ; Dec. 9, 1967; H. Yamashita leg.

\section{Distribution :}

This species is known from off Luzon, Philippines and Japan. In Japan it occurs along the Pacific coast northward to off Inubo-zaki and along the Sea of Japan northward to Kyo-gasaki, near the Wakasa Bay. Its bathymetric range is from 65 to $203 \mathrm{~m}$. 


\section{Goneplax nipponensis Yokoya 1933}

(Fig. 7)

Goneplax nipponensis Yokoya, 1933, p. 197, fig. 64-Japan (Suruga Bay ; near Omaë-zaki, Shizuoka Pref. ; south of Koshiki-jima Is. ; north of Goto Is. ; east of Mishima I., off Yamaguchi Pref.), 51-132 m deep.

Goneplax nipponensis : Sakai, 1939, p. 564-No new locality.

\section{Description :}

The carapace is strongly convex fore and aft, and bears no regional indication; its surface is entirely smooth. The front is slightly less than one-third the greatest breadth of the carapace ; it is weakly doubly rimmed and bears a small median process which is almost not visible from above ; each frontal lobe is somewhat concave, being slightly produced at the lateral angle. The supraorbital border bears a narrow crest, and runs longitudinally at the base of the eye-stalk and then obliquely-backward, being strongly sinuate. The infraorbital border is deeply and widely excavated near the inner infraorbital angle. The external orbital angle is armed with a strong spine which is slightly curved forward; behind the spine the lateral border of the carapace is rather strongly convergent, posterior two-thirds the dorsal surface along the borders being sunken.

In the ovigerous female the chelipeds and ambulatory legs are missing, and in the male the ambulatory legs are also missing. The male chelipeds are only slightly unequal, the right one being the larger. The merus bears a minute spine at little behind the middle portion of its upper border, and fringed with a row of granules and long plumose hairs along the lower border. The carpus is smooth except for just near its inner angle which is not at all produced. The palm is not swollen and is widened distally ; its outer surface is smooth and devoid of hairs, while its inner surface is provided with minute granules and short scant plumose hairs. The fingers are as long as, or only slightly shorter than the palm, being provided with four or five rather irregular teeth. The male abdomen tapers from the third to the distal segment which is once and a half as long as the preceding one. The first male pleopod bears numbers of stout setae; the second pleopod is subfiliform and much longer than the first pleopod.

\section{Material examined :}

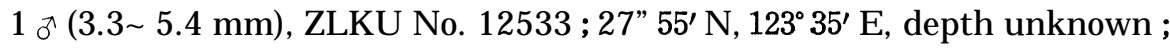
Apr. 9, 1962; H. Yamashita leg.

1 ovig. 우 (4.0 x $6.6 \mathrm{~mm})$, ZLKU No. 12534 ; 31" 19.5’ N, $127^{\circ} 32^{\prime} \mathrm{E}, 126 \mathrm{~m}$ deep ; Jun. 17, 1964; H. Yamashita leg.

\section{Remarks :}

According to the original description, the ambulatory legs are slender and 
unarmed at all. And also the merus of cheliped is said to be unarmed, though in the present male it is armed with a small submedian spinule. This species is characterized by the strongly convergent and unarmed lateral border of the carapace and the unarmed ambulatory legs. G. wolffi Serene from off New Caledonia is the nearest kin of this species. It is, however, said that the supraorbital border is more strongly sinuate, a low tubercle is demarcated on the lateral border of the carapace, and that the carpus of the cheliped is armed with a spine at its external boder.

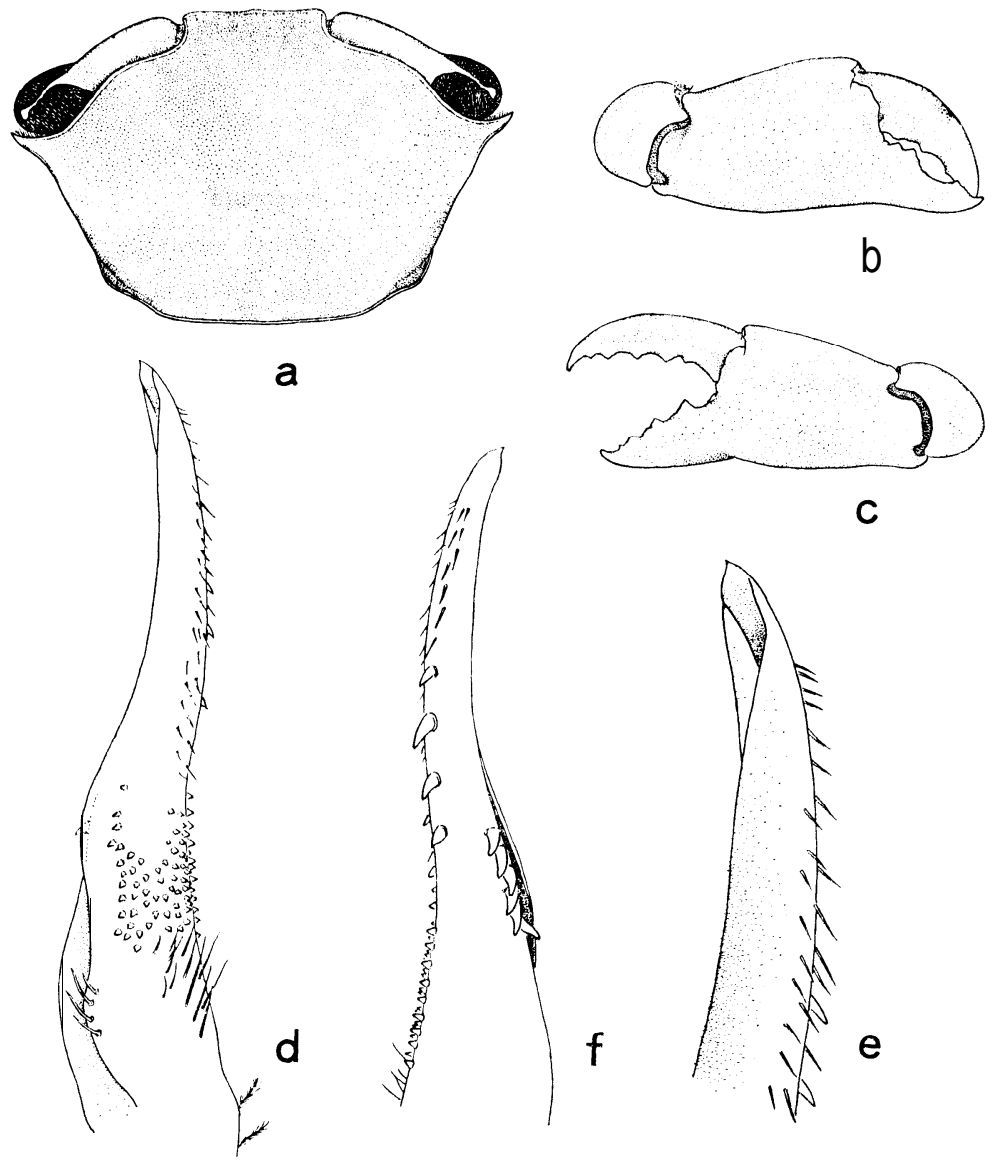

Fig. 7. Goneplax nipponensis Yokoya. a, Carapace of male $(3.3 \times 5.4 \mathrm{~mm})$, $\times 10$; b, c, right and left chelae of the same male, $\times 10$; , first pleopod of the same male in abdominal view, $\times 50$; e, distal portion of the same, $\times 100$; $\mathrm{f}$, the same in abdominal view, $\times 50$. 


\section{Distribution :}

This species has hitherto been known from the original several localities around Japan; it ranges from near Omaë-zaki southward to Kyushu, and to Mishima Island, off Yamaguchi Prefecture, the Sea of Japan. Its bathymetric range is from 51 to $132 \mathrm{~m}$.

\section{Typhlocarcinops transversa Tesch, 1918}

(Fig. 8, a, b, P1. 6, A)

Typhlocarcinops transversa Tesch, 1918, p. 212, pl. 14, fig. 3--Bay of Bima, north coast of Sumbawa, 13-31 m deep.

Typhlocarcinops transversa : Serene, 1964, p. 233, fig. 12, pl. 20, C-Sunda Strait $\left(6^{\circ} 38^{\prime} \mathrm{S}, 105^{\circ} 21^{\prime} \mathrm{E}\right) 35 \mathrm{~m}$ deep.

\section{Description :}

The carapace is very broad, and strongly bent down anteriorly so as to conceal the free edge of the front in dorsal view; the dorsal surface is rather well sculptured medially, and is covered with a short pubescence unmixed with long hairs which are restricted to the lateral borders. The front is medially grooved and bears a small median emargination, each lobe being little arched. The eye is, as usual, firmly fixed and embedded in the orbit, but the eye-stalk is so slightly protuberant and granulated that the contour of the carapace is shallowlly interrupted at the inner and outer angles of the orbit; the cornea is small and ventral-terminal, but well pigmented. The third maxillipeds almost completely close the buccal cavern; the merus is quadrate, its antero-external angle being somewhat produced. The lateral border of the carapace bears three interruptions which are not very wide, but are U-shaped sinus; three blunt teeth thus formed by those interruptions are not protruded from the general contour of the carapace; those teeth are bluntly crested and bordered with thick minute granules; the posterolateral portion of the lateral border is somewhat convergent posteriorly, and its dorsal surface near the border is roughly granulated.

The chelipeds are subequal in both sexes; the carpus is fringed with soft hairs most densely near the rounded and granulated inner angle. The palm is not much swollen, and. its upper border is rounded except for just near the proximal end where is blunty crested ; the proximal portion of the inner surface is deeply excavated; in the female the outer surface is entirely covered with a pubescence mixed with long hairs, while in the male the lower distal portion is devoid of it; beneath the pubescence the surface is entirely smooth except for a row of granules at the lower border. The outer surface of the immovable finger is impressed by a longitudinal cavity in which the pubescence is filled; the outer surface of the 
movable one is also channelled, but is devoid of hairs ; the cutting edges bear each four to six conical teeth, the tips being crossed.

The ambulatory legs are slender and unarmed. In the first pair the carpus and propodus are fringed with prominent two rows of long plumose hairs along near the upper borders; the carpus is othewise bordered with a row of similar hairs along its lower border ; the upper border of the dactylus is also provided with a row of plumose hairs in a line with that of the upper one of the carpus; it is furthermore provided with two rows, one on the upper surface, and the other along the lower border. In the second pair the carpus and propodus are provided with a row of plumose hairs instead of two rows of the preceding pair. In the following two pairs the hairs are scant and not arranged in a row. In the last pair the dactylus is prominently upturned.
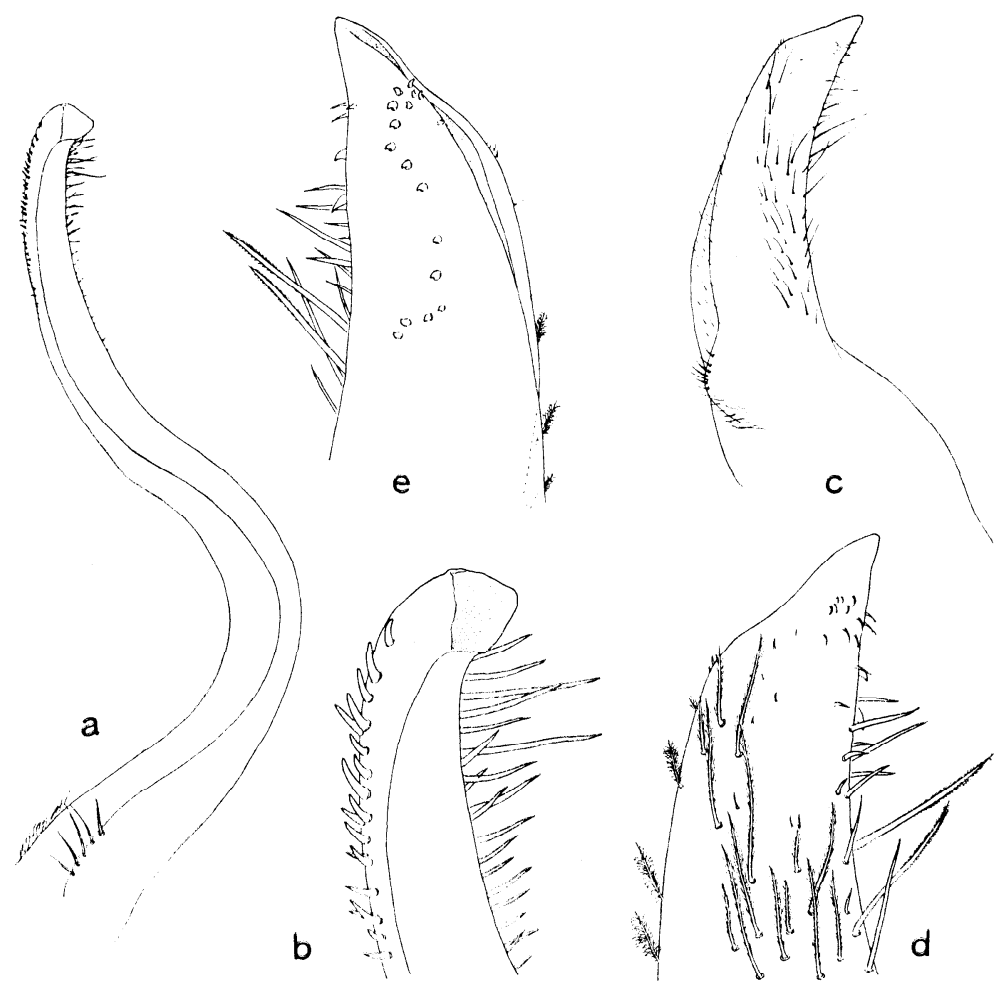

Fig. 8. Typhlocarcinops transversa Tesch. a, First pleopod of male $(6.0 \times 8.6 \mathrm{~mm})$ in abdominal view, $\mathrm{x} 41.5$; $\mathrm{b}$, distal portion of the same, $\times 100$.

Goneplax renoculis Rathbun. c, First pleopod of male $(5.2 \times 7.3$ $\mathrm{mm})$ in abdominal view, $\mathrm{X} 16.5$; d, distal portion of the same, $\times 80$; e, the same in sternal view, $\times 80$. 


\section{Material examined :}

1 ð (5.2x7.8 mm), ZLKU No. 12535 ; 29” 0.1' N, 124” 48.1' E, 82 m deep ; Jun. 29, 1962; H. Yamashita leg.

1 Ђ $(6.0$ x8.6 mm), 1 ð infested by Sacculina $\mathrm{sp} .(5.2 \times 7.6 \mathrm{~mm}), 1$ 우 damaged, ZLKU No. 12536; 28 47' N, 124” 50' E, 102 m deep ; Jun. 30, 1962 ; H. Yamashita leg.

\section{Remarks :}

In the present material the carapace is very broad, the breadth being nearly once and a half times its length, by which this species is distinguished from the closely allied species, T. marginata Rathbun and $\boldsymbol{T}$. gallardoi Serene. The present specimens are, however, disagreeable with the original description in some respects. In the present material the carapace is rather well sculptured medially, the lateral border of the carapace is provided with three blunt teeth which are formed by three U-shaped interruptions, and finally the outer surface of the palm is smooth beneath the pubescence, its upper border being rounded except near the proximal end. According to the original description, there is scarcely any trace of regions except for the longitudinal groove near the front, three blunt teeth are separated by very wide interspaces, and the palm is everywhere granulated, its upper border being sharply keeled.

In the present materials the first male plepod bears a triangular transparent beak at the tip; it is somewhat similar to that of $\boldsymbol{T}$. marginata represented by Serene (1964, fig. 10, c), but is different at the tip.

\section{Distribution :}

This species has hitherto been known from the Bay of Bima, north coast of Sumbawa, and Sunda Strait, at the depth of 13 to $35 \mathrm{~m}$. Here the bathymetric range is further extended to $102 \mathrm{~m}$.

\section{Typhlocarcinops ocularia Rathbun, 1914}

(Fig. 9, Pl. 6, B)

Typhlocarcinops ocularia Rathbun, 1914, p. 153-Destacado I., Philippines, $240 \mathrm{~m}$ deep.

Typhlocarcinops ocularia : Yokoya, 1933, p. 20X-North-west of Nagato, Yamaguchi Pref., $90 \mathrm{~m}$ deep and north of Mifogaseki, Shimane Pref., $75 \mathrm{~m}$ deep, Sea of Japan.

Typhlocarcinops ocularia : Sakai, 1939, p. 572-No new locality.

\section{Description :}

The carapace is narrow, being about 1.3 times as broad as long ; it is strongly vaulted antero-posteriorly, but almost flat from side to side; the 
dorsal surface is thickly covered with a very short, rusty pubescence mixed with soft, short club-shaped hairs ; in the largest male the pubescence is worn out at the middle portion of the dorsal surface ; those club-shaped hairs are thickly present near and at the lateral borders; at the anterior half of the lateral border those hairs are rather long and arranged in a row, while at the posterior half they are short and bear a ragged appearance; when the hairs are removed, the anterior portion of the lateral border is nearly entire and fringed with granules, and the posterior portion is only slightly convergent ; the posterolateral dorsal surface is minutely granulated and shallowly concave, but its posterior corner is not produced at all. The front is produced and bilobed, each lobe being strongly arcuate; the orbit is suborbicular, in which the eye is completely embedded; the cornea is small and ventral, being rather well pigmented. The third maxillipeds leave a narrow gape; the antero-external angle of the merus is not produced but rounded.

The chelipeds are slightly unequal. The carpus and palm are bordered with club-shaped ragged hairs, the greater surfaces being naked and polished ; the inner angle of the carpus is armed with a granular blunt tooth which is concealed under those hairs. The palm is somewhat compressed and bluntly crested on both the upper and the lower borders ; in the larger palm the lower border is nearly smooth, while the lower border of the smaller palm is bordered with granules. Both the movable and the immovable fingers are channelled near the outer upper and lower borders respectively; in the larger chela the movable finger bears three distant teeth, and three teeth are present at the proximal portion of the immovable one; in the smaller chela both the movable and the immovable fingers are rather irregularly but sharply toothed on the cutting edges.

The ambulatory legs are long and fringed with a row of long club-shaped hairs. In the last pair the dactylus is slightly upturned unlike those of the preceding pairs.

\section{Material examined :}

3 ठð (L argest ð, 9.9 $12.6 \mathrm{~mm}$ ), ZLKU No. 12539 ; $31^{\prime \prime} 30^{\prime} \mathrm{N}, 124^{\circ} 42^{\prime} \mathrm{E}$, $46 \mathrm{~m}$ deep ; Jul. 2, 1962 ; H. Yamashita leg.

1 우,ZLKU No. 12542; 31” N, 124²1.5' E, 45 m deep; Jul. 3, 1962; H. Yamashita leg.

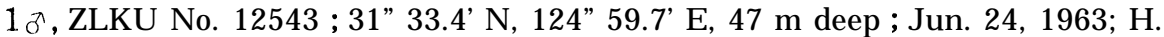
Yamashita leg.

\section{Remarks :}

According to the original description, the chelipeds are very unequal, and each finger of the larger chela bears a sharp tooth at the middle and a molar process at the base, which is divided into two or three teeth. The unequal chelipeds seem, however, to bear no specific value. This species 
is characterized by the following respects. (1) The lateral border of the carapace is nearly entire, and its posterolateral portion is only slightly convergent. (2) The front is produced, each lobe being arched. (3) In the third maxilliped the antero-external angle of the merus is not produced, but rounded. (4) The ambulatory legs are fringed with long club-shaped hairs. (5) The first male pleopod ends in a short triangular process.

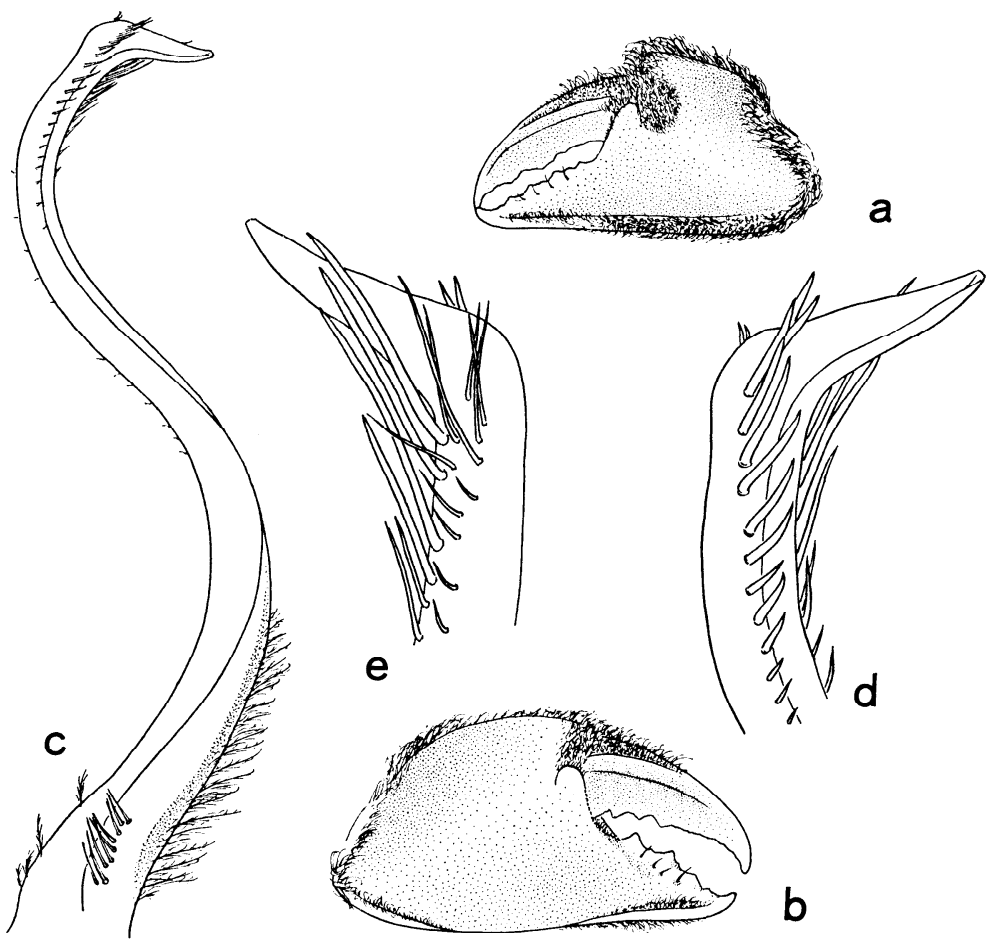

Fig. 9. Typhlocarcinops ocularia Rathbun. a, b, Right and left chelae of male $(7.4 \times 9.4 \mathrm{~mm}), \mathbf{X} 5$; $c$, first pleopod of the same male in abdominal view, $\mathrm{X} 21$; d, distal portion of the same, $\times 50$; e, the same in sternal view, $\mathbf{X} \mathbf{5 0}$.

\section{Distribution :}

This species has been known from Philippines, and off Yamaguchi and Shimane Prefectures, the Sea of Japan. The bathymetric range is from 45 to $240 \mathrm{~m}$. 


\section{Family Pinnotheridae}

\section{Pinnixa rathbuni Sakai, 1934}

Pinnixa occidentalis: Yokoya, 1928, p. 775, fig. 6-Aomori Bay, Japan.

Pinnixa occidentalis: Yokoya, 1933, p. 208--Several localities of Pacific coast of Japan from east of Shioya-zaki, Aomori Pref. southward to east of Owase, Mie Pref., 37-132 m deep.

Pinnixa rathbuni Sakai, 1934b, p. 39, fig. l-Ise Bay and Sagami Bay, Japan.

Pinnixa rathbuni: Sakai, 1936, p. 201, fig. 105-Japan.

Pinnixa rathbuni : Sakai, 1939 , p. 559, fig. 83-No new locality.

Pinnixa rathbuni: Miyake, 1961, p. 174-Sea of Ariaké, Japan.

Pinnixa rathbuni: Sakai, 1965b, p. 182, pl. 88, fig. 2-Sagami Bay, 65-85m deep.

\section{Material examined:}

1 ð (4.2x7.7 mm), 1우, ZLKU No. 12544 ; 37” 15.3’ N, 125 E, 65 m deep ; Nov. 8, 1966; H. Yamashita leg.

\section{Remarks :}

The present species is very characteristic in the male chelae; the immovable finger is very short and triangular, bearing a strong tooth near the base, while the movable finger bears a small tooth and is so strongly curved downward that an extensive hiatus is left when the fingers are closed. It is noted that in the posterior two pairs of the ambulatory legs each carpus and propodus are provided with a blunt, granulated crest on the the upper borders, and that the lower border of the propodus is also granulated.

\section{Distribution :}

This species has been known from the Pacific coast of the Japanese waters; it ranges from the Aomori Bay southward to the coast of Kagawa Prefecture. Its bathymetric range is from 37 to $132 \mathrm{~m}$.

\section{A sthenognathus inaequipes Stimpson, 1858}

Asthenognathus inaequipes : Stimpson, 1907, p. 140, pl. 14, fig. l-Off east coast of Japan in latitude, 38" N, $54 \mathrm{~m}$ deep.

Asthenognathus inaequipes : de Man, 1907, p 392, pl. 31, figs. 4-6-Inland Sea of Japan.

Asthenognathus inaequipes : Balss, 1922, p. 141-Japan.

Asthenognathus inaequipes: Yokoya, 1928, p. 778-Aomori Bay, 22-49 m deep.

Asthenognathus inaequipes : Sakai, 1936, p. 206, fig. ll-Japan.

Asthenognathus inaequipes : Sakai, 1939, p. 601, fig. 86-Mutsu Bay, Onagawa Bay 
near Sendai, and Osaka Bay, Japan,

Asthenognathus inaequipes : Miyake, 1961, p. 175-Sea of Ariake, Japan.

Asthenognathus inaequipes : Sakai, 1965b, p. 182, pl. 88, fig. 4-Sagami Bay, 65 $\mathrm{m}$ deep.

\section{Material examined :}

1 우(6.7 $\times 9.8 \mathrm{~mm})$, ZLKU No. 12545 ;32³0. $2^{\prime} \mathrm{N}, 123^{\circ} 2^{\prime} \mathrm{E}, 34 \mathrm{~m}$ deep ; Mar. 16, 1963; H. Yamashita leg.

\section{Remarks :}

The other representative from the Indo-Pacific waters, A. hexagonum Rathbun from the Gulf of Siam, is very close to this species. It is, however, said that the carapace is much narrower, being more strongly hexagonal.

\section{Distribution :}

This species is endemic in Japan, and has previously been known from the Mutsu Bay, Sendai Bay, Sagami Bay, Osaka Bay and Inland Sea of Japan. The bathymetric range is from 22 to $65 \mathrm{~m}$.

\section{X enophthalmus pinnotheroides White, 1846 (Fig. 10)}

Xenophthalmus pinnotheroides White 1846, p. 178, pl. 2, fig. 2-Philippines.

Xenophthalmus pinnotheroides: Adams and White, 1848, p. 63, pl. 12, fig. 3-No new locality.

Xenophthalmus pinnotheroides : Stimpson, 1907, p.141-Hongkong, $11 \mathrm{~m}$ deep.

Xenophthalmus pinnotheroides: Henderson, 1893, p. 394-Rameswaram, India.

Xenophthalmus pinnotheroides : Alcock, 1900, p. 332-No new locality.

Xenophthalmus pinnotheroides: Rathbun, 1910, p. 338, fig. 22-Gulf of Siam, 11$18 \mathrm{~m}$ deep.

Xenophthalmus pinnotheroides : Tesch, 1918, p. 272-Djangkar, east coast of Java, $9 \mathrm{~m}$ deep, and Sapeh Bay, east coast of Sumbawa, $36 \mathrm{~m}$ deep.

? Xenophththalmus pinnotheroides : Stephensen, 1945, p. 186, fig. 54-Persian Gulf and Strait of Hormuz.

Xenophthalmus pinnotheroides : Shen, 1948, p. 113, fig. 4-Shantung Penin., China. Xenophthalmus pinnotheroides : Miyake, 1961, p. 175-Sea of Ariaké, Japan.

\section{Material examined:}

1 ovig. 우 (6.9 x 9.5 mm), ZLKU No. 12546 ; 31” 12.4’ N, 12337.8’ E, 47 m deep ; Jul. 4, 1962; H. Yamashita leg.

1 juv., ZLKU No. 12547 ; 31” 31' N, 1233 31.5’ E, 40 m deep ; Oct. 11, 1962 ; H. Yamashita leg. 


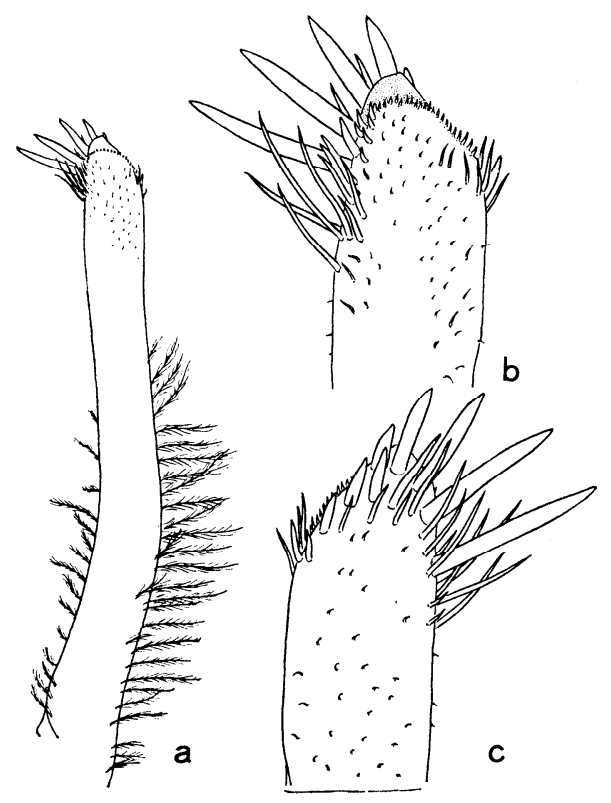

Fig. 10. Xenophthalmus pinnotheroides White. a, First pleopod of male $(5.7 \times 7.6 \mathrm{~mm})$ in abdominal view, $X$ $21 ; b$, distal portion of the same, $\mathrm{X} 50$; c, the same in sternal view, $\mathrm{x} 50$.
2 ðð, 2 우우, 7 juv., ZLKU No. 12548 ; 32" 16.5 ' N, $122^{\circ} 31^{\prime} \mathrm{E}, 32 \mathrm{~m}$ deep; Oct. 11, 1962; H. Yamashita leg.

5 ðð, 4 우우 (Largest 우, $9.4 \times 13.1$ $\mathrm{mm}), 6$ juv., ZLKU No. 12552 ; 32" $30.2^{\prime} \mathrm{N}, 123^{\circ} 2^{\prime} \mathrm{E}, 34 \mathrm{~m}$ deep ; Mar. 16, 1963; H. Yamashita leg.

1 ð $(5.8 \times 7.4 \mathrm{~mm})$, ZLKU No. 12567 ; 33” 35.3’ N, 122 27' E, $32 \mathrm{~m}$ deep ; Mar. 17, 1963; H. Yamashita leg.

\section{Remarks :}

This characteristic species was elaborately described by Tesch (1918) ; the orbit which is completely filled by the club - like eyestalk is longitudinal and entirely parallel to each other, so that the narrow front is clearly defined laterally from the orbits. The third maxilliped is curious in shape; the dactylus is upturned and directed backward towards the base of the carpus; the propodus

and dactylus are densely fringed with long feathered hairs which cover the anterior part of the buccal cavern.

In the specimens from the East China Sea, even in the largest male, the chelipeds are exceedingly weak and slender as in Tesch's description, being much shorter than the first pair of the ambulatory legs. In many male specimens from the Sea of Ariaké, the chelae are much higher and stronger than the female chelae. Otherwise, it is not correct that Tesch described the female abdomen being narrow like that of the male. In the adult female the abdomen is very wide and quite different from that of the male. The first male pleopod is described by the same author as "obtuse at the tip which is armed with a bunch of slender spines." At present the description is proved to be sure as represented in Fig. 10. Though the first male pleopod was also represented by Stephensen (1945), it terminates in a narrow process, at the base of which there are several spines of different length and shape. It is surely the same type, but different from that of the present material. 


\section{Distribution :}

This species is known from the Indian Ocean and the West Pacific: Rameswaram in Gulf of Manaar; Gulf of Martaban; Gulf of Siam ; Djangkar, Java ; Sapeh Bay, Sumbawa ; Hongkong ; Philippines ; Japan. The record of the occurrence in the Persian Gulf needs to be secured. In Japan it is known from the Sea of Ariaké. The bathymetric range is from the intertidal zone to $47 \mathrm{~m}$.

\section{Family Palicidae}

\section{Palicus hatusimaensis Sakai, 1963}

(Fig. 11)

Palicus hatusimaesis Sakai, 1963, p. 230, fig. 7, c-Sagami Bay, Japan, 30-50 m deep. Palicus hatusimaensis: Sakai, 1965b, p. 185, pl. 89, fig. 3-Sagami Bay, 85 m deep.

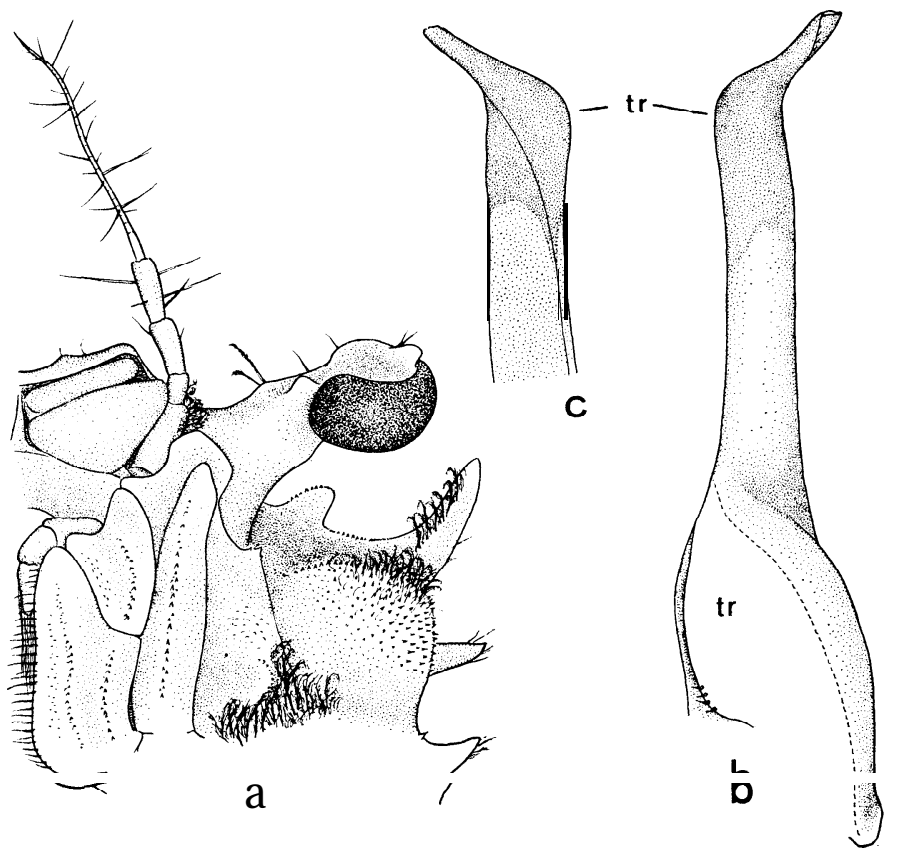

Fig. 11. Palicus hatusimaensis Sakai. a, Orbital and buccal regions of ovigerous female $(3.4 \times 4.2 \mathrm{~mm})$ in abdominal view, $\times 25 ; \mathrm{b}$, first pleopod of male $(2.7 \times 3.2 \mathrm{~mm})$ in abdominal view, $\times 60 ; c$, distal portion of the same in sternal view, $\times 60$. Abbreviation used. tr : transparent. 


\section{Material examined :}

1 ovig. 우 (4.2 mm in breadth), ZLKU No. 12568 ;31 29.2’ $\mathrm{N}, 130^{\circ}$ ' $1.5^{\prime} \mathrm{E}$, 196 m deep; Jun. 13, 1964; H. Yamashita leg.

1 đ, 2 ovig. 우우, 2 우우, ZLKU No. 12569; 31” 19.5’ N, 127³2’ E, $126 \mathrm{~m}$ deep; Jun. 17, 1964; H. Yamashita leg.

1 ovig. 우, 1 우, ZLKU No. 12574 ; 32” 0.6’ N, 127 12' E, 120 m deep ; Jun. 17, 1964; H. Yamashita leg.

3 ठð (Largest ð, $2.7 \times 3.2 \mathrm{~mm}$ ), 2 우우 (Largest 우, $3.8 \sim 4.5 \mathrm{~mm}$ ), ZLKU No. 12576; $33^{\circ} 9.2^{\prime} \mathrm{N}, 128^{\prime \prime} 1.4^{\prime}$ E, $158 \mathrm{~m}$ deep ; Jun. 18, 1964; H. Yamashita leg.

1 ovig. 우, ZLKU No. 12581; 33” 23.4' N, 129³.9’ E, $100 \mathrm{~m}$ deep ; Jun. 18, 1964; H. Yamashita leg.

\section{Remarks :}

This small crab is characterized by the armatures of the dorsal surface and lateral borders of the carapace; the dorsal surface is uneven, each areola being studded with tubercles of various size; the front is bilobate, and the inner border of each lobe is marked with a small tooth which is sometimes low and indistinct; a prominent tooth is present between the supraorbital eave and the externl orbital tooth which is very prominent and directed obliquely forward; behind the external orbital tooth the lateral border is armed with larger two and following two or three small teeth; the posterior border is furnished with four equidistant teeth. In the ambulatory legs all the dactyli are not foliaceous but slender. The first male pleopod is well calcified and bears the transparent, twisted beak at the tip.

\section{Distribution :}

This species has hitherto been known only from the Sagami Bay at the depth of 30 to $85 \mathrm{~m}$. Here the bathymetric range is extended to $196 \mathrm{~m}$.

\section{Acknowledgements}

The present authors must express their hearty thanks to Mr. Hideo Yamashita of the Seikai Regional Fisheries Reserch Laboratory for providing them many valuable materials. One of the authors (M. T.) is indebted to Dr. Tune Sakai of the Yokohama National University for his kind guidance. It is noted that as a foundation of the present work Sakai's The Crabs of Sagami Bay (1965) has been taken. 


\section{Literature}

Adams, A. \& A. White, 1848. Crustacea. The zoology of H.M.S. "Samarang." London, i-viiii, 1-66, pls. 1-13.

Alcock, A., 1898. Materals for a carcinological fauna of India. No. 3. Brachyura Cyclometopa. Part 1. The family Xanthidae. J. Asiat. Soc. Bengal, 67: 67-233.

- 1899. Ditto. No. 4. Brachyura Cyclometopa. Part 2. The families Portunidae, Cancridae and Corystidae. ibid., 68: I-103.

—, 1900. Ditto. No. 6. Brachyura Catometopa or Grapsoida. ibid., 69: 280-456.

Balss, H., 1922. Ostasiatische Decapoden. IV. Die Brachyrhynchen (Cancridae). Arch. Naturg., ser. A, 88 : 94-166, pls. 1, 2.

- 1932. Ueber einige systematisch interessante Xanthidae (Crustacea, Decapoda Brachyura) der Harmschen Reisen nach dem Sundaarchipel. Zeitschr. Wiss. Zool., 142: 510-519.

Barnard, K. H., 1950. Descriptive catalogue of South African decapod Crustacea. Ann. S. Afr. Mus., 38 : 1-837.

Borradaile, L. A., 1902. Marine crustaceans. 3. The Xanthidae and some other crabs. In: The fauna and geography of the Maldive and Laccadive Archipelagoes. 1: 237-271.

-, 1916. Crustacea. Part 1. Decapoda. British Antarctic ("Terra Nova") Expedition, 1910. Nat. Hist. Rep., Zool., 3: 75-110.

Buitendijk, A. M., 1950. On a small collection of Decapoda Brachyura, chiefly Dromiidae and Oxyrhyncha, from the neighbourhood of Singapore. Bull. Raffles Mus., 21: 59-82.

Doflein, F., 1902. Ostasiatische Decapoden. Abh. K. B. Akad. Wiss., II Cl., 21: 611-670, pls. 1-6.

—, 1904. Brachyura. Wiss. Ergebn. Deutsch. Tiefsee-Exped., "Valdivia" 1898-1899. Jena, 6: i-xiv, 1-314.-Atlas, pls. 1-58.

Gordon, I., 1938. On three species of Portunidae (Decapoda, Brachyura) from the Malay Peninsula. Bull. Raffles Mus., 14: 175-185.

Guinot, D., 1967. Recherches préliminaires sur les groupements naturels chezlescrustacés décapodes brachyoures. II. Les anciens genres Micropanope Stimpson et Medaeus Dana. Bull. Mus. Nat. Hist. nat., Paris, ser. 2, 39: 345-374.

Haan, W. de, 1833-1850. Crustacea. In: Fanua Japonica sive descriptio animalium, quae in itinere per Japoniam, jussu et auspiciis superiorurn, qui summum in India Batava Imperium tenent, suscepto, annis 1823-1830 collegit, notis observationibus et abumbrationibus illustravit. i-xvii, i-xxxi, 1-244, pls. 1-55, A-Q, 1, 2.

Haswell, W. A., 1882. Catalogue of the Australian stalk- and sessile-eyed Crustacea. Sydney, 1-324, pls. 1-4.

Henderson, J. R., 1893. A contribution to Indian carcinology. Trans. Linn. Soc. London, ser. 2, Zool., 5: 325-458, pls. 36-40.

Hilgendorf, F., 1878. Die von Herrn Dr. Peters in Mozambique gesammelten Crustaceen. Monatsber. K. Preuss. Akad. Wiss., Sitzb. phys.-math. K1., Berlin, 1878: 782-851, pls. $1-4$.

Illustration of the zoology of the royal Indian marine survey ship Investigator, under the command of Commander T. H. Heming, R.N. Crustacea, Part 7, 1899, pls. 36-45.

Klunzinger, C. B., 1913. Die Rundkrabben (Cyclometopa) des Roten Meeres. Abh. K. Leop.-Caral. Deutch. Akad. Naturf., 99: 97-402, pls. 5-11.

Leene, J.E., 1938. The Decapoda Brachyura of the Siboga-Expedition. VII. Brachygnatha : Portunidae. Siboga-Exped., Monogr., 39c, Leiden, I-156. 
Man, J. G. de, 1887-1888. Report on the podophthalmous Crustacea of the Mergui Archipelago, collected for the trustees of the Indian Museum, Calcutta, by Dr. John Anderson, F.R.S., Superintendent of the Museum. J. Linn. Soc. London, Zool., 22:1-312, pls. $1-19$.

- 1888. Bericht iiber die von Herrn Dr. J. Brock in Indischen Archipel gesammelten Decapoden und Stomatopoden. Arch. Naturg., 53: 215-600, pls. 7-22a.

- 1907. On a collection of Crustacea, Decapoda and Stomatopoda chiefly from the Inland Sea of Japan, with description of new species. Trans. Linn. Soc. London, ser. 2, Zool., 9: 325-458, pls. 36-40.

McNeill, F. A. \& M. Ward, 1930. Carcinological notes. No. 1. Rec. Aust. Mus., 17: $357-$ 383, pls. 59-61.

Miers, J. E., 1879. On Crustacea from the Corean and Japanese Sea. Proc.zool. Soc. London, 1879: 18-61, pls. 1-3.

- 1881. On a collection of Crustacea made by Baron Hermann-Maltzam at Goree Island, Senegambia. Ann. Mag. nat. Hist., ser. 5, 8: 259-281, 364-377, pls. 13-16.

- 1886. Report on the Brachyura collected by H.M.S. Challenger during 1873-1876. Rep. sci. Res. voyage H.M.S. Challenger, Zool., 17: i-L, 1-362, pls. 1-29.

Milne Edwards, A., 1865. Etudes zoologiques sur les crustacés récents de la famille des cancériens. Nouv. Arch. Mus. Hist. nat, Paris, 1: 177-308, pls. 11-19.

- 1873a. Recherches sur la faune carcinologique de la Nouvelle-Caledonie. II. ibid., 9: 155-332, pls. 4-18.

- 1873 b. Description de quelques crustacés nouveaux ou peu connus. Mus. Godeffroy J., 1 : 77-88, pls. 1, 2.

Miyake, S., 1936. Report on the Brachyura of Riukiu Islands collected by the Yaéyama Expeditions during the years 1932-1934. I. Notes on a new and some rare crabs from Iriomote-shima. Ann. Zool. Jap., 15: 494-502, pls. 35, 36.

$\longrightarrow$, 1961. A list of the decapod Crustacea of the Sea of Ariaké, Kyushu. Rec. oceanogr. Wks. Japan, spec. 5: 165-178.

Nobili, G., 1906. Fauna carcinologique de la Mer Rouge. Décapodes et stomatopodes. Ann. Sci. nat. Zool., ser. 9, 4: 1-347, pls. 1-11.

Odhner, T., 1925. Monographierte Gattungen der Krabben-familie Xanthidae, I. Göteborgs K. Vet.-och Vit.-Samh. Handl., 29: 1-92, pls. 1-5.

Ortmann, A., 1893, Die Decapoden-Krebse des Strassburger Museums, mit besonderer Beriicksichtigung der von Herrn Dr. Döderlein bei Japan und bei den Riu-Kiu Inseln gesammelten und zur Zeit im Strassburger Museum aufbewahrten Formen. VII. Brachyura. II. Cyclometopa. Zool. Jahrb., Syst., $7: 411-495$, pl. 17.

—, 1894. Ditto. VIII. Brachyura. III. Catometopa. ibid., 7: 683-772, pl. 23.

Palmer, R., 1927. A revision of the genus “Portunus" (A. Milne Edwrds, Bell etc.). J. mar. Ass. U. K., 14: 877-908.

Parisi, B., 1916. I decapodi giapponesi del Museo di Milano. IV. Cyclometopa. Atti Soc. It. Sci. nat., 55: 5-42, pls. 7-11.

—, 1918. Ditto. VI. Catometopa e Paguridea. ibid., 57 : 90-115, pl. 8.

Paulson, O., 1961 (1875). Studies on Crustacea of the Red Sea with notes regarding other Sea. Part 1. Podophthalmata and Edriophthalmata (Cumacea). "English translation of the original Russian publication" The Israel Program for Scientific Translation, Jerusalem. 1-164, pls. 1-21.

Rathbun, M. J., 1902. Japanese stalk-eyed crustaceans. Proc. U. S. Nat. Mus., 26: 23-55. 
- 1910. The Danish Expedition to Siam 1890-1907. V. Brachyura. D. Kgl. Danske Vidensk. Skrifter, 7 : 303-367, pls. 1, 2.

—, 1911. The Percy Sladen Trust Expedition to the Indian Ocean in 1905. 3 (11). Marine Brachyura. Trans. Linn. Soc. London, ser. 2, Zool., 14: 191-261, pls. 15-20.

- 1914. A new genus and some new species of crabs of the famliy Goneplacidae. Proc. U. S. Nat. Mus., 48: 137-154.

Richters, F., 1880. Decapoda. In: Meeresfauna der Insel Mauritius und der Seychellen. Berlin, 139-178, pls. 15-18.

Sakai, T., 1934a. Brachyura from the coast of Kyushu, Japan. Sci. Rep. Tokyo Bunrika Daigaku, sec. B, 1: 281-330.

- 19346. Species of the genus Pinnixa (pinnotherid crab) found in the Far East. ibid., $2: 37-43$.

- 1935. New or rare species of Brachyura, collected by the "Misago" during the zoological survey around the Izu-Peninsula. ibid., 2: 63-88, pls. 7, 8 .

- 193'6. Crabs of Japan. 66 plates in life coloures with description. Tokyo, 1-239, 1-12, pls. 1-66, frontispiece (in Japanese).

- 1939. Studies on the crabs of Japan. IV. Brachygnatha, Brachyrhyncha. Tokyo, 365-741, pls. 42-111.

- 1963. Description of two new genera and 14 new species of Japanese crabs from the collection of His Majesty the Emperor of Japan. Crustaceana, 5: 213-233.

-1965a. On two new genera and five new species of xanthoid crabs from the collection of His Majesty the Emperor of Japan made in Sagami Bay. ibid., 8: 97-106.

—, 1965b. The crabs of Sagami Bay. Tokyo, i-xvi, 1-206, 1-92, 1-32, pls. 1-100.

Serène, R., 1964. Goneplacidae et Pinnotheridae. Papers from Dr. Th. Mortensen's Pacific Expedition 1914-1916. 80. Vidensk. Medd. fra Dansk. naturh. Foren., 126: 181-282, pls. 16-24.

Shen, C. J., 1932. The brachyuran Crustacea of North China. 2001. Sinica, ser. A, 9 : I-320, pls. $1-10$.

- 1935. On a new species of Charybdis, belonging to the subgenus Gonioneptunus, from South Africa. Ann. Mag. nat. Hist., ser. 10, 15: 404-408.

- 1948. On a collection of crabs from the Shantung Peninsula, with notes on some new and rare species. Contr. Inst. Zool., Peiping, 4: 105-117.

Stephensen, K., 1945. The Brachyura of the Iranian Gulf. Danish sci. Invest. Iran. Part IV. Copenhague, 57-237.

Stephenson, W., 1961. The Australian portunids (Curstacea: Portunidae) V. Recent collections. Aust. J. mar. fr eshw. Res., 12 : 92-128, pls. 1-5.

—, \& B. Campbell, 1959. Ditto. III. The genus Portunus. ibid., 10: 84-124, pls. 1-5.

—, Hudson, J. \&-, 1957. Ditto. I. The genus Charybdis. ibid., 8: 491-507, pls. 15.

Stimpson, W., 1907. Report on the Crustacea (Brachyura and Anomura) collected by the North Pacific exploring expedition 1853-1856. Smiths. misc. Coll., 49: I-240, pls. 1-26.

Tesch, J. J., 1918. The Deapoda Brachyura of the Siboga Expedition. II. Goneplacidae and Pinnotheridae. Siboga-Exped., Monogr., 39c ${ }^{1}$, Leiden, 149-295, pls. 7-18.

Ward, M., 1933, New genera and species of marine Decapoda Brachyura from the coast of New South Wales and Queensland. Aust. Zool., 7: 377-394, pls. 21-23.

White, A., 1846. Notes on four new genera of Crustacea. Ann. Mag. nat. Hist., 18: 176178.

- 1848. Short descriptions of new or little-known decapod Crustacea. ibid., ser. 2, 2: 282-288. 
Whitelegge, T., 1900. Crustacea. Part 1. Scientific results of the trawling expedition of H.M.C.S. "Thetis," off the coast of New South Wales, in February and March, 1898. Aust. Mus. Mem., 4: 135-199, pls. 32-35.

Yamashita, H., 1965. On the growth of the cheliped of Carcinoplax Zongimanus (de Haan). Res. Crust., 2: 10-18 (in Japanese with English summary).

Yokoya, Y., 1928. Report of the biological survey of Mutsu Bay. 10. Brachyura and crabshaped Anomura. Sci. Rep. Tohoku Imp. Univ., ser. 3, 3: 757-784.

- 1933. On the distribution of decapod crustaceans inhabiting the continental shelf around Japan, chiefly based upon the material collected by S. S. Soyo-Maru, during the year 1923-1930. J. Coll. Agr., Tokyo Imp. Univ., 12: 1-226.

\section{Explanation of Plate 6}

Fig. A. Typhlocarcinops transversa Tesch. $\sigma^{\top}(5.2 \times 7.6 \mathrm{~mm})$ infested by Sacculina sp.

Fig. B. Typhlocarcinops ocularia Rathbun. $\sigma^{\top}(7.2 \times 9.2 \mathrm{~mm})$.

Figs. C, D. Glabropilumnus sodalis (Alcock). Ovig. 우 (9.2X14.6 mm). 

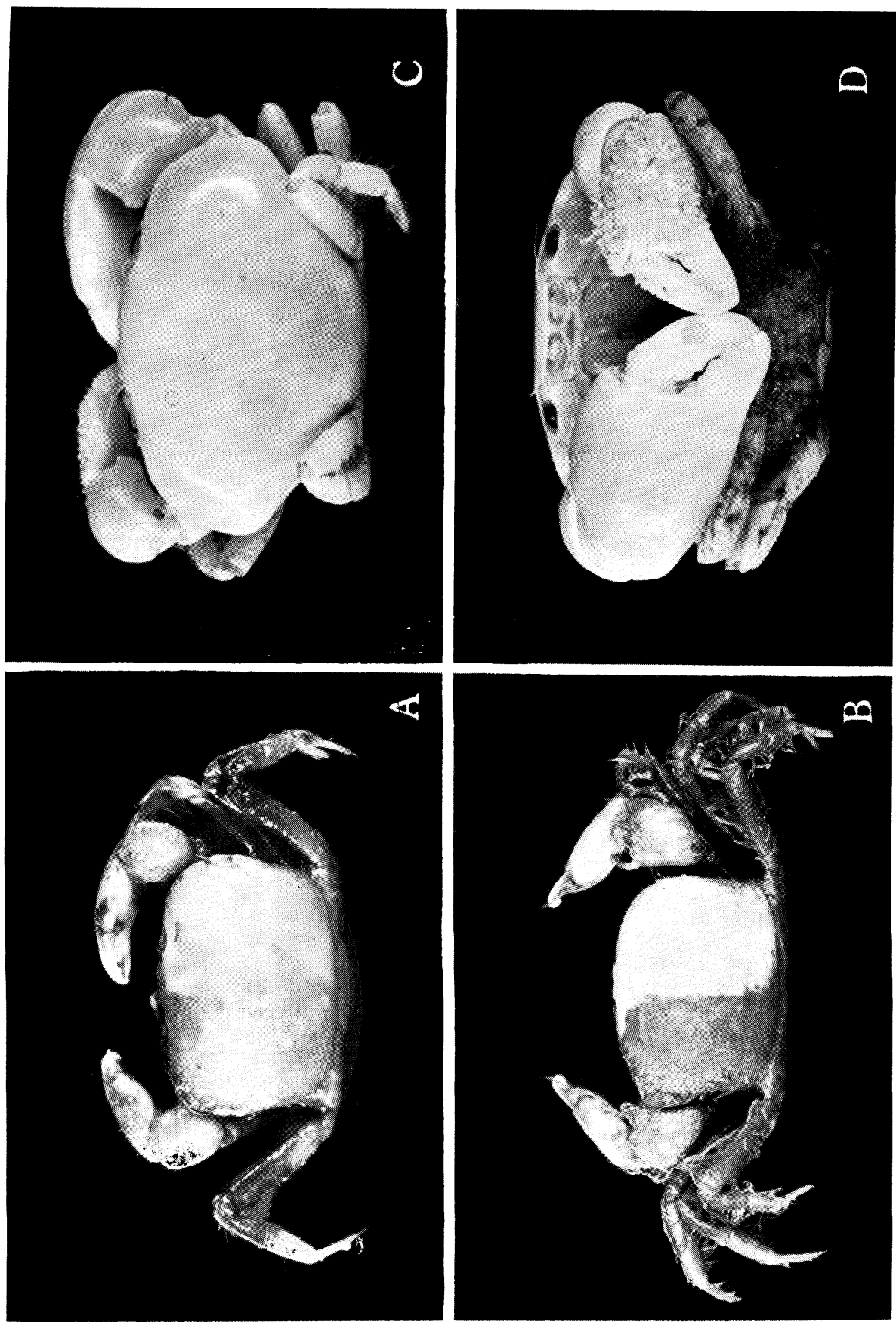

Crabs from the East China Sea 